\title{
Measuring hours worked in Germany - Contents, data and methodological essentials of the IAB working time measurement concept
}

\author{
Susanne Wanger ${ }^{1} \cdot$ Roland Weigand $^{1} \cdot$ Ines Zapf $^{1}$
}

Published online: 6 September 2016

(C) The Author(s) 2016. This article is available at SpringerLink with Open Access.

\begin{abstract}
This article presents the Working Time Measurement Concept of the Institute for Employment Research, which determines the hours worked in Germany and their individual components. The Working Time Measurement Concept is the key data product on working time in Germany and underlies the German national accounts figure on labour input. These statistics on hours worked are essential for a proper analysis of aggregate labour market trends and cyclical fluctuations. In the Working Time Measurement Concept, changes in working hours due to collective agreements and economic fluctuations are brought together with shifts in employment structure, thus producing a differentiated picture of the scope, structure and development of the annual working time of gainfully employed persons. We outline the conceptual and methodological framework of the measurement, which continually evolves due to its integration in the system of national accounts and due to innovations to the statistical procedures applied. An overview of single components and their data sources is given, while the resulting time series of hours worked and the volume of work are depicted according to their long run trends, cyclical variation and reaction in the 2008/09 financial and economic crisis.
\end{abstract}

Susanne Wanger

Susanne.Wanger@iab.de

Roland Weigand

Roland.Weigand@iab.de

$\triangle$ Ines Zapf

Ines.Zapf@iab.de

1 Institute for Employment Research (IAB), Regensburger Strasse 104, 90478 Nuremberg, Germany
Keywords IAB working time measurement concept . Hours worked · Volume of work · Components · Persons in employment $\cdot$ System of national accounts

JEL classification $\mathrm{C} 82 \cdot \mathrm{E} 01 \cdot \mathrm{J} 2$

\section{Die Berechnung der geleisteten Arbeitsstunden in Deutschland - Inhalte, Daten und methodische Grundlagen der IAB Arbeitszeitrechnung}

Zusammenfassung Der vorliegende Aufsatz stellt die Arbeitszeitrechnung des Instituts für Arbeitsmarkt- und Berufsforschung vor, die die Arbeitszeit in Deutschland sowie deren einzelne Komponenten ermittelt. Die Arbeitszeitrechnung ist das Schlüsselprodukt zu den geleisteten Arbeitszeiten in Deutschland und liegt den Statistiken zum Arbeitseinsatz in den Volkswirtschaftlichen Gesamtrechnungen zugrunde. Diese Statistiken zu den geleisteten Arbeitsstunden sind von großer Bedeutung für die umfassende Analyse von Arbeitsmarkttrends sowie von konjunkturellen Entwicklungen. In der Arbeitszeitrechnung werden Veränderungen bei geleisteten Arbeitsstunden aufgrund von tariflichen Vereinbarungen und konjunkturellen Schwankungen mit dem Wandel der Beschäftigtenstruktur zusammengebracht und ergeben somit ein differenziertes Bild von Umfang, Struktur und Entwicklung der Jahresarbeitszeit der Erwerbstätigen. Wir stellen den konzeptionellen Rahmen des Rechenwerks dar, der einerseits durch die Einbindung in die Volkswirtschaftlichen Gesamtrechnungen, andererseits durch Neuerungen in der statistischen Methodik laufend weiterentwickelt wird. Es wird ein Überblick über die einzelnen Komponenten und deren Datenbasis gegeben, bevor die resultierenden Zeitreihen $\mathrm{zu}$ Arbeitszeit und Arbeitsvolumen bezüglich ihrer langfristigen Trends, ihres zykli- 
schen Verhaltens, und ihrer Reaktion auf die Finanz- und Wirtschaftskrise 2008/09 untersucht werden.

\section{Introduction}

Regular and trustworthy data on hours worked and their components over longer periods of time are indispensable for applied research in economics and the social sciences. Consider the tracking of major labour market trends, such as the increasing flexibility of working-time arrangements, the replacement of paid overtime by transitory overtime hours, as well as the long-term increase in part-time employment. These developments are of significant importance for policymakers and provide interesting facts to be faced and explained by researchers.

Business cycle analysis is another area where high-quality measures of working-time matter. Traditionally, cyclical fluctuations of labour input and hourly productivity are used to assess the empirical validity of real business cycle theories; see e. g. Kydland and Prescott (1982) and Hansen (1985). More recently, the reaction of these indicators to identified shocks (see e. g. Gali 1999), or equilibrium deviations like the so-called 'labour wedge' (Chari et al. 2007; Shimer 2010) have been studied in order to identify empirically tenable theories. Likewise, the accounting of the reactions to the global financial and economic crisis of 2008/09 draws heavily on hours worked data; cf. Burda and Hunt (2011). Ohanian and Raffo (2012) highlight the importance of internationally comparable data on hours worked and compile a data set on hours worked for OECD countries using official national accounts statistics where available.

Official data on hours worked in Germany are provided by the Working Time Measurement Concept (Arbeitszeitrechnung, AZR) of the Institute for Employment Research (IAB). The AZR is the key data product on working time in Germany and underlies the German national accounts figure on labour input. The two key indicators provided by the AZR are the hours worked per employed person and the labour volume, which is the product of hours worked per employed person and the number of persons in employment (Reyher and Kohler 1986; Kohler and Reyher 1988). ${ }^{1}$ Because the AZR is based on a componentwise accounting system, changes in working hours due to collective agreements and economic fluctuations are brought together with shifts in employment structure and produce a differentiated picture of the scope, structure and development of the annual working time of gainfully employed

\footnotetext{
${ }^{1}$ Other terms for labour volume which are synonymously used in this article are volume of work, hours worked by all employed persons, overall hours worked in the economy, yearly hours actually worked etc.
}

persons. The results of the AZR on hours worked and the labour volume offer a unique basis for the evaluation of labour market developments and further perspectives.

Working time measurement has a long tradition at the IAB: Already in 1969 a differentiated approach was developed to record yearly hours actually worked per employed person and the labour volume. The development of the AZR occurred against the background that the statistical recording of actual working hours was initially far from satisfactory. Only statistical fragments of varying quality and definition were available, which is one of the reasons why empirical analyses on diverse issues related to working time and the volume of work did not meet elementary requirements for a long time, and why shortcomings persist.

Over the years, changing labour market policies, the increasing flexibility of working time, but also improved data availability entail continuous conceptual development of the AZR (cf. Bach 2001; Koch 2001; Bach and Koch 2002; Wanger 2003, 2013; Wanger et al. 2014). The AZR was refined and deepened, but also adjusted to changes in working time reality. It has gradually evolved to become an important basis of national and international empirical economic and labour market research. Thus, the aggregated results of the AZR have been included into the quarterly national accounts of the German Federal Statistical Office since 1996. Consequently, they are also a component of Germany's data transmissions to the Statistical Office in the European Union (Eurostat).

This article is addressed both to applied researchers in the social sciences and to experts from statistical agencies who are involved in the construction and maintenance of statistical systems such as national accounts. The research community is provided with an overview over the different facets of working time the AZR sheds light on, which is important to spur research using this data source for a large variety of interesting questions. At the same time, the discussion of the conceptual framework in this paper gives important advice for scholars working with the data. The data sources and their timeliness are important to assess potential sampling and non-sampling errors of the individual components, the working assumptions made in their computations, and the time lag after which reliable estimates are available. While several components make use of data from the full population and are available almost in real time, as is the case, e.g., for sick leave and short time work, other sources are available with a considerable time lag or allow only estimates with relevant sampling errors, as, e. g., household surveys. Also the trustworthiness of disaggregated data, say at industry level, is different across components, and the current paper also hints at related limitations and caveats applying for practical use cases of the data. 
Fig. 1 Components of hours worked in the Working Time Measurement Concept

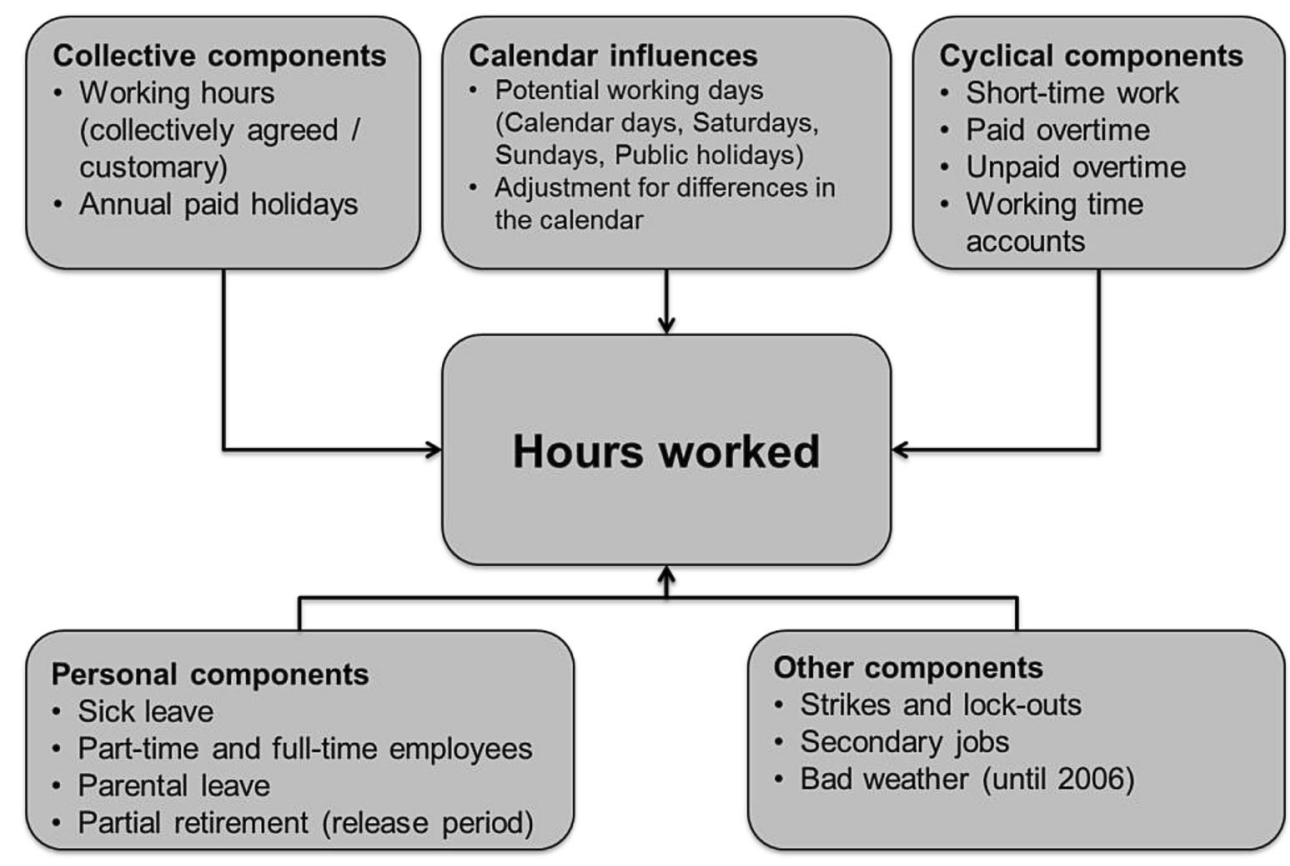

With respect to statistical agencies and their representatives, the current paper contributes to the discussion on the proper compilation of national accounts and similar products from different data sources. In addition to serving as a proposal concept specifically for working time accounting, where an internationally accepted gold standard has not evolved so far, overall principles like model-based statistical nowcasting, as applied in the AZR in various components, might be of interest also in other branches of official statistics.

In short, this article is structured as follows: Sect. 2 introduces the basic concept of the AZR. In Sect. 3 the single components of working time are presented along with their data sources and measurement concepts. Sect. 4 provides selected results on working time, such as long term trends, cyclical properties, and the reaction in the 2008/09 financial and economic crisis, before Sect. 5 gives a short summary.

\section{Basic concept of the AZR}

\subsection{Component accounting}

The calculation of hours worked and the volume of work within the framework of the AZR is based on a differentiated componentwise accounting concept, where calendar effects, collectively agreed standards, business cycle influences as well as personal and other components are considered (Fig. 1). As a result, the AZR provides quarterly consistent time series for the development of hours worked and their components as well as for the labour volume in
Germany since $1991 .^{2}$ Working hours are calculated separately for dependent employees as well as for the self-employed persons and family workers, resulting in the working hours of all gainfully employed persons. They include all hours worked by persons who have several jobs at the same time. However, hours paid but not worked, for example because of annual leave, parental leave, holidays, shorttime work or sick leave, are not part of the labour volume. All components are broken down into full-time and parttime employment, into West and East Germany, and into 38 economic sectors, known as the $\mathrm{A} * 38$ aggregates according to the WZ 2008 classification of economic branches (European Commission 2008). ${ }^{3}$

Following a bottom-up concept, the starting point for the calculations of hours worked and the volume of work is the number of employees on the one hand and the number of potential working days on the other hand. Based on

\footnotetext{
${ }^{2}$ Comprehensive quarterly and annual results of the AZR are published regularly and can be freely retrieved from the IAB web page (www.iab.de). The results and estimates of hours worked are also incorporated into the labour market short-time projections of the IAB (cf. Fuchs et al. 2015). The Federal Statistical Office also regularly publishes quarterly and annual results on the average number of hours worked and the labour volume together with employment figures and the GDP (Fachserie 18 National Accounts). See Fachserie 18, Series 1.4 Volkswirtschaftliche Gesamtrechnungen, Inlandsproduktsberechnung - Detaillierte Jahresergebnisse (only available in German)/Fachserie 18, Series 1.2 National Accounts - Domestic Product - Quarterly results/Fachserie 18, Series 1.3 Domestic Product Seasonally adjusted quarterly results, available via https://www.destatis. de.

3 Additionally, hours worked are calculated separately for men and women as well as age groups in a subsystem (cf. Wanger 2006, 2011, 2015).
} 
Table 1 The simplified model of calculating the components of the IAB Working Time Measurement Concept and how they add up to the total volume of work
Calculations for employees

Component of volume of work

Collectively agreed/customary volume of work

- Volume of paid holidays

- Volume of sick leave

+ Volume of paid overtime

+ Volume of unpaid overtime

\pm Volume of flows on working-time accounts

- Volume of short-time work

- Volume of bad weather (until 2006)

- Volume of strikes and lock-outs

\pm Volume of adjustments for differences in the calendar

+ Volume of secondary jobs

$=$ Volume of work of employees $\left(H_{E}\right)$

Calculations for self-employed and family workers

Component of volume of work

Normally worked volume of work

- Volume of holidays

- Volume of sick leave

+ Volume of secondary jobs

\section{Calculation}

Daily working hours $(w h) *$ working days in period $(\mathrm{wd}) *$ number of employees $(\mathrm{E})$

Paid holidays * wh * E

(Adjusted) sick leave in \%* wd $*$ wh $* \mathrm{E}$

Daily paid overtime $*$ wd $* \mathrm{E}$

Daily unpaid overtime $*$ wd $* \mathrm{E}$

Daily transitory overtime $* \mathrm{wd} * \mathrm{E}$

Short-time worker * percentage loss of working hours per short-time worker * working hours in period (adjusted for sick leave)

Affected employees * number of lost hours Lost days by strikes and lock-outs * wh

(1) Long term working hours (ltwh) $=$ (longterm working days/working days in period) * coll. agreed/customary working hours in period (cwh)

$(2)-(\mathrm{cwh}-\mathrm{ltwh}) *($ inverse $)$ working-dayselasticities * E

Persons with secondary jobs * working hours in secondary jobs in period

\section{Calculation}

Daily working hours (whs) * working days of self-employed and family workers (wds) * selfemployed and family workers (S)

Holidays $*$ whs $* \mathrm{~S}$

Sick leave in $\% *$ whs $*$ wds $* \mathrm{~S}$

Persons with secondary self-employed jobs * working hours in secondary jobs in period

$=$ Volume of work of self-employed and family workers $\left(H_{S}\right)$

these, the collectively agreed or customary volume of work for employees is calculated; see Table 1. Proceeding from this, we calculate a loss or additional volume of work for each component using the available data, e. g., on holiday leave, sick leave, paid and unpaid overtime hours, transitory overtime hours, short time work, bad weather, strikes, adjustments for calendar effects and secondary employment. The results for all single components are brought together in one overall figure to obtain the hours worked per employee as well as for all employees (the labour volume). Likewise, for self-employed and family workers a smaller number of relevant components, like holidays, sick leave, and secondary jobs, are used to adjust the normally performed volume of work for that group.

This componentwise accounting concept combines administrative data sources, survey-based data and household surveys to measure hours worked in accordance with the rules of official statistics (cf. Sect. 2.3). Due to the numerous components and dimensions to be considered in the AZR, a total of 20 different statistics and surveys are processed (Table 2) to cover all areas with sufficient information. As a consequence, the measurement concept faces differing sources, periodicities, types of surveys and degrees of coverage, while additionally some of the data sources are available only with a substantial publication lag. This explains the need of model-based estimation procedures for some components (see Sect. 2.2). The componentwise concept allows selecting suitable methods for the estimation of each component.

As in the overall calculation of hours worked and the labour volume, we calculate the results for each component following a bottom-up approach in principle. The disaggregated results by status in employment, by industry and by region are aggregated to a macroeconomic outcome. Hence, also the aggregated labour volume can be decomposed according to

$$
\boldsymbol{H}_{\text {Total }}=\sum_{i=1}^{38} \sum_{j=1}^{2} \sum_{k=1}^{2} \boldsymbol{H}_{\boldsymbol{E}, \boldsymbol{i} \boldsymbol{j} \boldsymbol{k}}+\sum_{i=1}^{38} \sum_{j=1}^{2} \boldsymbol{H}_{\boldsymbol{S}, \boldsymbol{i} \boldsymbol{j}}
$$


Table 2 The most important data sources of the IAB Working Time Measurement Concept

\begin{tabular}{|c|c|c|}
\hline $\begin{array}{l}\text { Components of hours } \\
\text { worked }\end{array}$ & Data Source & Data Provider \\
\hline Employees & Employment Accounts & Federal Statistical Office \\
\hline \multirow[t]{4}{*}{ Part-time and full-time } & Employment Accounts & Federal Statistical Office \\
\hline & Employment Statistics & Federal Employment Agency \\
\hline & $\begin{array}{l}\text { Statistics on Public Service Person- } \\
\text { nel }\end{array}$ & Federal Statistical Office \\
\hline & Microcensus & Federal Statistical Office \\
\hline \multirow[t]{5}{*}{ Weekly workings hours } & $\begin{array}{l}\text { Index of Agreed Earnings and } \\
\text { Working Hours Calculation }\end{array}$ & Federal Statistical Office \\
\hline & WSI Collective Agreement Archive & Hans Böckler Foundation \\
\hline & IAB Establishment Panel & Institute for Employment Research \\
\hline & Microcensus & Federal Statistical Office \\
\hline & Register of Collective Agreements & $\begin{array}{l}\text { Federal Ministry of Labour and So- } \\
\text { cial Affairs }\end{array}$ \\
\hline \multirow[t]{4}{*}{ Annual paid holidays } & Microcensus & Federal Statistical Office \\
\hline & WSI Collective Agreement Archive & Hans Böckler Foundation \\
\hline & Monthly Tourism Survey & Federal Statistical Office \\
\hline & Birth Statistics & Federal Statistical Office \\
\hline \multirow[t]{2}{*}{ Sick leave } & $\begin{array}{l}\text { Statutory Health Insurance Statis- } \\
\text { tics }\end{array}$ & Federal Ministry of Health \\
\hline & Health Reports & Statutory health insurance companies \\
\hline \multirow[t]{3}{*}{$\begin{array}{l}\text { Paid and unpaid } \\
\text { overtime }\end{array}$} & $\begin{array}{l}\text { German Socio-Economic Panel } \\
\text { (GSOEP) }\end{array}$ & $\begin{array}{l}\text { German Institute for Economic Re- } \\
\text { search }\end{array}$ \\
\hline & Microcensus & Federal Statistical Office \\
\hline & Ifo Business Survey & Ifo Institute \\
\hline Short-time work & $\begin{array}{l}\text { Statistics on Short-Time Work of } \\
\text { Businesses and Short-Time Work- } \\
\text { ers }\end{array}$ & Federal Employment Agency \\
\hline Strikes and lock-outs & Strike Statistics & Federal Employment Agency \\
\hline \multirow[t]{2}{*}{ Working-time accounts } & IAB Establishment Panel & Institute for Employment Research \\
\hline & GSOEP & $\begin{array}{l}\text { German Institute for Economic Re- } \\
\text { search }\end{array}$ \\
\hline \multirow[t]{2}{*}{ Secondary jobs } & Employment Statistics & Federal Employment Agency \\
\hline & Microcensus & Federal Statistical Office \\
\hline $\begin{array}{l}\text { Adjustments for differ- } \\
\text { ences in the calendar }\end{array}$ & Working Days Elasticities & German Bundesbank \\
\hline \multirow{2}{*}{$\begin{array}{l}\text { Self-employed persons } \\
\text { including family workers }\end{array}$} & German Employment Account & Federal Statistical Office \\
\hline & Microcensus & Federal Statistical Office \\
\hline
\end{tabular}

where

$H_{E}=$ Volume of work of employees

$H_{S}=$ Volume of work of self-employed and family workers

$i=$ industries

$j=$ regions

$k=$ status in employment (full-/part-time).

This approach is demanding in terms of the availability of sector-specific data, but offers a great potential for structural sector research. Table 3 gives an overview of the subdivision of the AZR.

Not each primary statistic provides sufficiently rich sector-specific data to allow for precise estimation, however. In order to enhance disaggregated estimates, ancillary statistics are used for some components (see Sects. 3.3 and 3.5).
In some cases where sector-specific data are subject to larger sampling errors but the aggregates are precisely estimated, a top-down approach is used so that the macroeconomic aggregate is used to benchmark the disaggregated industry figures (see, e. g., Sects. 3.5, 3.6.1 and 3.6.2). In cases where the top-down approach is used, the calculations for some industries are afflicted with relatively large uncertainties associated with small domain-specific sample sizes, but these do not affect the macroeconomic outcome.

Since the calculation of hours worked and the labour volume within the componentwise accounting concept is demanding, different approaches for the measurement of working hours are used by other data producers. E. g., Eurofound calculates a collectively agreed yearly working time 
Table 3 Overview of the subdivision of the IAB Working Time Measurement Concept

\begin{tabular}{ll}
\hline Hours worked and volume of work by \\
\hline $\begin{array}{l}\text { Status in } \\
\text { employment }\end{array}$ & $\begin{array}{l}\text { Persons in employment } \\
\text { Employees (full-time, part-time) } \\
\text { Industries }\end{array}$ \\
& Self-employed persons including family workers \\
& By 21 industries (quarters) \\
Region & Germany \\
& West Germany \\
& East Germany (incl. Berlin) \\
"Subsystems" & By gender \\
& By nine age-groups \\
Time & Quarterly, 1991 up to the current year \\
\hline
\end{tabular}

on the basis of collective agreements for all EU member states for the purpose of cross-country comparisons (Cabrita 2014).

As another alternative, measurements of hours worked and volume of work can be derived directly from survey interviews. For most of the establishment surveys, however, the findings are limited to particular groups of persons or companies, questions relate to paid hours rather than actual hours worked, or interviews take place only infrequently. Also in household interviews, e. g., labour force surveys, the questions to record hours actually worked and not worked, respectively, are not sufficient to yield a solid overall figure. Besides typical problems with household surveys such as proxy interviewing or memory errors, questions on "hours actually worked last week" or similar questioning may induce a systematic bias due to underreported occurrence of components such as holidays or sick leave which cause interviews not to take place. Likewise, multiple jobholding is underreported by survey participants as was found by Steward (2014) for U.S. data. Fleck (2009), who also discusses several other shortcomings of surveys when measuring hours worked, shows that, all in all, the hours worked series estimated directly from labour force surveys provide higher measures as compared to other concepts.

In contrast to direct survey estimates, our comprehensive measurement concept contributes to a precise estimation of the overall and industry-specific volume of work since full coverage statistics are used where available to reduce the impact of survey errors and biases. Additionally, early available official numbers such as the sick leave ratio reported by health insurers replace survey results published with a substantial time lag, and thus contribute to the timeliness of reliable estimates. By using inputs such as employment by industries and person groups directly from other contributors to the national accounts, the accounting system becomes more consistent and reliable as compared to a concept where representativeness of household surveys is relied on. Most obviously, the AZR improves upon survey questions on "hours worked last week" as the impact of the different components of working time can be separately assessed. This allows the user to analyse the influence of the components, while the contribution and relevance of these numerous different developments can still be presented in an overall figure, such as the annual change of average hours worked.

As a flipside of the componentwise approach with multiple data inputs, it is not possible to compute standard errors of the final estimates in a conceptionally straightforward way for several reasons (see Carson and Laliberté 2002 for a related discussion regarding national accounts statistics). Firstly, the uncertainty related to key inputs such as the number of persons employed, which is itself estimated using multiple sources, is not available. This precludes attempts to quantify the uncertainty if one is not willing to make ad-hoc assumptions on the errors of these components. Secondly, a possible quantitative assessment of uncertainty would include sampling errors, but would necessarily ignore survey biases, errors induced by working assumptions in the accounting concept, and summingup constraints, such that error bands would be overly optimistic. Thirdly, the uncertainty of an estimate is timedependent at least for recent quarters due to the permanent inflow of data sources, since survey errors interact with model-based nowcasting errors. At least the latter are mutually dependent across working time components so that the overall uncertainty cannot be assessed for recent figures which are arguably the most interesting ones for policy applications.

Statistical agencies have proposed alternative, more qualitative ways to assess the accuracy of national accounts, including analysis of revisions and judgmental valuation of the different components (Carson and Laliberté 2002), but an adoption to the current framework is beyond the scope of this text and therefore left as a future development step of the AZR.

\subsection{Model-based statistical methods}

In addition to the componentwise accounting model and the data sources summarized above, model-based statistical methods used to extract information from the data inputs constitutes the third key building block of AZR. Affecting several modules of the AZR such as secondary jobs, sick leave, paid and unpaid overtime and flows on working time accounts, model-based statistical techniques are an elementary feature of the AZR as a whole. The methods may be of interest to statistical agencies beyond their role in the computation of working time components described below.

For many components of hours worked, the data basis is incomplete, or it hinders a straightforward design-based 
computation for other reasons. Missing data points may occur if the source does not range back to 1991, if the original data are of a lower, e.g. yearly, frequency, or if the data are collected according to reference dates rather than in a continuous way. Furthermore, long publication lags of some survey or administrative data intricate the computations at the current edge. Finally, data gaps as well as statistical breaks occur if data sources undergo revisions or surveys are restructured. In contrast to these cases of missing information, there is often more than one primary source for a specific component to measure. This poses an additional challenge for the statistician wishing to honour the available sources properly.

Under such circumstances, a model-based estimation strategy is called for, which helps estimate the unknown quantities by making efficient use of the available data. Recently, state space methods have become a valuable tool in official statistics; see e. g. Durbin and Koopman (2012) for a textbook treatment and Pfeffermann and Tiller (2006) as well as Krieg and van den Brakel (2012) for recent applications in official statistics. The state space approach combines assumptions on the dynamics of the underlying series with a suitable model for the measurements by observed data. Corresponding filtering and smoothing algorithms produce estimates of the underlying time series, which borrow strength from several data sources, related variables and from its own past.

During the recent revision of the AZR, state space models have been installed as a major methodological innovation. For the most part, univariate or multivariate structural time series models, with separately modelled trend, seasonal, cyclical and irregular components, are used as dynamic specification. Since that revision, the application of such models, for example, helps to face the publication delay of secondary jobs, allows us to treat missing data periods and statistical breaks in the part-time ratio of regularly employed persons, and enables us to construct quarterly sick leave estimates from official data available for reference dates and additional sources; see Wanger et al. (2014) for more details on the specific models for each component. The most comprehensive use of state space models in the AZR is for the business cycle related components overtime hours and net flows on working-time accounts. There, Weigand et al. (2015) propose and implement a model in which the information of several primary surveys, but also additional business cycle and labour market indicators are exploited. This is made possible by using a factor structure in the statistical model.

For each use case of state space methods in the AZR, the final estimates are forced to match the corresponding survey or administrative data source where available. Hence, no spurious fluctuations are induced, but rather data gaps at the current edge or within the series are filled. To understand both the overall level and main movements of the series, it is sufficient to focus on data sources rather than nowcasting methods in Sect. 3 when discussing the individual components.

\subsection{Integration in the national accounts and statistical concepts}

Due to the integration of the AZR in the national accounts, and to enhance international comparability, the "European System of National and Regional Accounts 2010" (ESA 2010) is essential for the calculation of hours worked. The ESA 2010 specifies the concepts, definitions, classifications and accounting rules to be applied by statistical agencies of the European Union (EU) when compiling national accounts. ${ }^{4}$ In addition, it contains the frequency and timing of the transmission program. As a European regulation, the ESA 2010 is directly legally binding for all EU Member States, and hence comparable harmonized data should exist throughout Europe to support political and economic decisions (cf. Federal Statistical Office 2013). Consequently, also the definition of hours worked and labour volume in the AZR is based on ESA 2010 (European Commission 2013a), where binding requirements are provided in line with the recommendations of the International Labour Organisation (ILO) (ILO 2008). When calculating hours worked and the labour volume, the AZR draws on national accounting figures of the Federal Statistical Office, particularly on Employment Accounts (cf. Lüken 2012), and on the Production Accounts of Gross Domestic Product (GDP) (cf. Mai 2010).

These national accounts figures are subject to regular revisions, which are distinguished into ongoing revisions and major revisions, also referred to as "general revisions" (cf. Räth and Braakmann 2014). Ongoing revisions are possible to each date of delivery, but they are only carried out for the recent past. At the main calculation date in August of each year, the data revision is limited to the last four years. In contrast, major revisions also comprise recalculations for the whole period to avoid breaks in the time-series. Therefore, fundamental revisions and further methodological developments in the AZR are synchronized with the general revisions of the national accounts, and these are usually carried out at intervals of five to ten years (cf. Lüken 2012).

\footnotetext{
${ }^{4}$ ESA 2010 replaced the previous ESA 1995 in September 2014. ESA 2010 is based on the global "System of National Accounts 2008" (SNA 2008) of the United Nations, but it includes some more precise rules for the EU countries, as EU countries are more homogeneous in economic terms (European Commission 2013a). See also: Regulation (EU) No 549/2013 of the European Parliament and the Council of 21 May 2013 on the European system of national and regional accounts in the Community (European Commission 2013b).
} 
Especially the recent general revision 2014 led to fundamental changes regarding the concept, the methods and therefore the resulting time series of the AZR. As an important innovation, the new component "unpaid overtime" was added, which has become necessary due to the changeover to ESA 2010. Another key part of the methodological changes was due to the introduction of state space methods as described above. Hence, in the course of the revision also the components paid overtime and working-time accounts were revised and now model-based estimation methods are applied. The 2014 revision also introduced a correction for artificial variation in the official sick leave ratio. Furthermore, we took into account several data revisions of the Employment Statistics of the Federal Employment Agency (BA). Consequently, the revision of single components affects the calculation of actual hours worked on average and the volume of work. In the course of the revision, however, the average annual working time and the labour volume, both for employees and for all persons in employment, did not change dramatically. The deviations in the single observation years (1991-2013) are between -1.6 and $+0.5 \%$ with respect to the average annual working time of employees and between -1.8 and $+0.2 \%$ with respect to the average annual working time of all persons in employment. Regarding the volume of work of employees the deviations range from -0.5 to $+1.8 \%$, while differences in the labour volume of all persons in employment are between -0.8 and $+1.3 \%$. More detailed comparisons of the results for the single components and calculated time series are given by Wanger et al. (2014).

As the AZR is integrated in the national accounts, a regular data exchange is carried out, which is organized in cooperation between the IAB, the Federal Statistical Office as well as the "Arbeitskreis Erwerbstätigenrechnung des Bundes und der Länder". ${ }^{5}$ At binding delivery dates, sectoral data for hours worked and labour volume are transmitted to the national accounts.

\section{Single components of the AZR}

In this section, we provide detailed information about the single components and the steps of their calculation. We describe the components in the natural order in which they add up to the overall results as shown in Table 1 . At the same time, the classification to the categories of working time as introduced in Fig. 1 is reflected by the ordering.

\footnotetext{
5 This working group consists of the statistical offices of the 16 German states (Länder), the Federal statistical office as well as the German association of Cities and Towns and has the task to calculate and publish official employment statistics for the individual states and urban and rural districts (http://www.aketr.de/aketr.hestala.de/index.html).
}

\subsection{Part-time and full-time employees}

To calculate the average actual hours worked and the volume of work, the number of gainfully employed persons is calculated and their structure is considered. The number of gainfully employed persons comprises employees subject to social insurance contributions, marginally employed persons, civil servants, and persons in work opportunities (Personen in Arbeitsgelegenheiten, so-called One-Euro-Jobs) as well as self-employed persons and family workers (for further details see Appendix B). The quarterly and annual figures stem from the Employment Accounts (cf. Lüken 2012). As there is no specific subdivision in the Employment Accounts according to working time, one fundamental element of the AZR is the allocation of employees into part-time or full-time employees. For calculating the part-time rate, different statistics are combined in the AZR.

The register-based Employment Statistics of the BA is the basis for calculating the number of part-time and full-time employees subject to social insurance contributions. It is based on standardised social security notifications, which include all employees (also those in vocational training) subject to compulsory health insurance, compulsory pension insurance or compulsory insurance in accordance with the German Social Code, Book III (SGB III). With this notification, employers also provide information on whether the employee has a full-time or a part-time job. Part-time employment is defined by contractual hours of work below the company's customary hours. However, the regular weekly working hours of the employees are not submitted. Breaks in the time-series of the Employment Statistics of the BA due to changes in the notification procedure (cf. Dundler and Frank 2012; Bertat et al. 2013) or a modernized data processing (cf. Frank and Grimm 2014) have been removed using a structural time-series model (cf. Wanger et al. 2014).

Marginally employed persons are a special form of parttime employees. They are not subject to social insurance contributions, but considered as gainfully employed following the labour force concept of the ILO if they performed at least one hour of paid work within the reporting period. Marginal employees are calculated by the Employment Accounts. Here, three groups of marginal employed persons are summarized: marginally gainful employed persons (socalled Mini-Jobs), marginally short-term employed persons and persons in One-Euro-Jobs.

Since civil servants are not subject to compulsory health and pension insurance, and compulsory insurance in accordance with SGB III, they are not included in Employment Statistics of the BA. Currently, the number of part-time civil servants is taken from the Fachserie 14, Series 6 "Personal des öfentlichen Dienstes" published by the Federal Statistical Office. By adding the regularly part-time employees 
subject to social insurance contributions, the marginal parttime employees including persons in One-Euro-Jobs and the part-time civil servants we get the number of all part-time employees. Furthermore, persons on parental leave and persons in the release period of partial retirement (cf. Wanger 2009) are considered as part-time employees. These persons are included as employed in the statistics but perform zero hours of work, which is taken into account to avoid an overestimation of the macroeconomic volume of work. The part-time rate represents persons employed part-time as a percentage of all employees.

\subsection{Potential working days}

In the calculations of the number of potential working days a five-day week is assumed throughout. This common assumption presumes that employees are given compensatory time off on other days when they work on saturdays, sundays, or on public holidays. ${ }^{6}$ The number of potential working days therefore results from the number of calendar days minus saturdays, sundays, and public holidays. Regional holidays that do not apply throughout Germany are weighted with the number of employees subject to social insurance contributions within the states (Bundesländer) level to calculate averages. The different numbers of annual working days have a nonnegligible irregular effect on annual hours worked. In addition to the resulting number of days, the effect of working days on the collectively agreed annual working time is presented in Table A.1 (see Appendix A). The corresponding line in the lower part of Table A.1 shows the percentage change of collectively agreed working time compared with the previous year due to an increase or decrease of the potential working days.

\subsection{Collectively agreed or customary working hours}

The collectively agreed or customary weekly working hours is the major source of the long-term development of hours worked. Collectively agreed hours worked are collected in the Index of Agreed Earnings and Working Hours Calculation (cf. Bick and Decker 2013). There, the development of collectively agreed income and working hours of employees in Germany is recorded together with indices of agreed earnings. Additionally, information from the Collective

\footnotetext{
${ }^{6}$ According to evaluations on basis of the GSOEP, about 1/10 of employees are working 6 or 7 days a week while this proportion is reducing gradually over time. The distribution of hours worked is unknown, however. Note that ignoring deviations from a 5-day-week may induce overestimation of calendar effects, but changes neither the overall level nor the cyclical behaviour of hours worked. This effect is partly adjusted for by the corrections described in Sect. 3.9. The GSOEP is a longitudinal survey of approximately 11,000 private households in Germany. For more information see e. g. http://www.diw.de/de/soep.
}

Agreement Archive of the Institute of Economic and Social Research (WSI) of the Hans-Böckler Foundation and the Register of Collective Agreements of the Federal Ministry of Labour and Social Affairs are added to cover gaps. Many industries have agreed on labour-related opening clauses and flexible working time regulations in the collective bargaining process, but since the actual use of such numerous variations on the enterprise level is not recorded or evaluated in the statistics, in particular the collectively agreed working hours is regarded as reference level for a certain period.

These data, however, cover only the weekly hours worked by employees in establishments with collective agreements. Results from the IAB Establishment Panel show that in establishments with collective agreements the weekly working hours are fewer than in those without collective agreements. Collective bargaining coverage decreased over the past years (cf. Ellguth and Kohaut 2014). Thus, the customary working hours in establishments which are not bound by collective agreements gain importance. This must be considered in the AZR since otherwise the component of collectively agreed or customary working hours is estimated too low. Through analyses of the $I A B$ Establishment Panel, a correction factor is estimated for each industry, which compensates for this effect.

Information on collectively agreed or customary working hours typically refers to full-time employment. Information from the Microcensus ${ }^{7}$ is used to obtain the average weekly hours worked by part-time employees. For the different economic sectors, the ratio of hours worked by regular part-time and marginal employees to those of fulltime employees is calculated. The results are then applied to the collectively agreed or customary working hours by full-time employees. For One-Euro-Jobs, information on average weekly hours worked are obtained from the BA. Because there is no differentiation according to economic sectors in this statistic, the variation of the working time of One-Euro-Jobbers across economic sectors is assumed to be proportional to that of marginal employees.

\subsection{Annual holiday leave}

According to the Federal Holidays Act (Bundesurlaubsgesetz), the minimum entitlement to paid recreational holiday is 20 working days per year based on a five-day work week. Many collective or individual agreements, however, include more favourable regulations. Overall, the annual leave en-

\footnotetext{
7 The Microcensus is an annual household survey covering roughly $1 \%$ of the population in Germany. The Labour Force Survey of the European Union (EU Labour Force Survey) forms an integral part of the Microcensus. For more information see e. g. https://www.destatis. de/EN/Meta/abisz/Mikrozensus_e.html.
} 
titlement for workers covered by collective agreements in Germany is six weeks per year (cf. Schnitzlein 2011). The Collective Agreement Archive of the WSI reports this collectively agreed annual paid holiday leave of employees, distinguishing basic and actual total leave by industries. Collective agreements can determine basic leave for an employee, which is then raised in one or more stages to the actual total leave. Requirements for an increase can be age, duration of affiliation with the enterprise, wage bracket, etc. Based on details provided by the WSI, basic and actual total leave are weighted on a 40/60 basis to obtain the overall leave, which is a plausible proportion also according to analyses of the GSOEP.

The quarterly distribution of the annual holiday leave is estimated with the help of the Monthly Tourism Survey (Federal Statistical Office), which includes the guest-nights by nationals in places of accommodation. The Collective Agreement Archive of the WSI additionally provides information on special leave which is customary in some economic sectors and hence also included in the AZR.

Besides the collectively agreed annual paid holiday leave, also times of maternity leave are considered. Based on the Birth Statistic of the Federal Statistical Office, the number of births by female employees is estimated via the ratio of female employees to the female population (of age 20-40). The corresponding volume of lost working hours can be calculated via the times of protection of six weeks before and eight weeks after giving birth. The ratio of female employees to the female population is established using the Microcensus. Furthermore, special effects of additional leave for heavy or hazardous work, school holidays for teachers, and additional leave for the severely handicapped, are also taken into account. Rough calculations indicate an average of about one day per year on average per employee.

\subsection{Sick leave}

The benchmark figure for the calculation of sick leave is the monthly sick leave ratio, which is measured in $\%$ of compulsory members of the state health insurance scheme with continued payment of wages of at least six weeks. ${ }^{8}$ The sick leave ratio is an official recording by the Statutory Health Insurance Statistics of the Federal Ministry of Health based on reporting dates. It comprises employees that reported unfit for work at the first of each month. The periods of short-term incapacity for work lasting up to three

\footnotetext{
8 Today, approximately one third of the German population are obligatory members of the statutory health insurance. Together with retired persons and family members the share increases to $87 \%$ according to the National Association of Statutory Health Insurance Funds. Another $11 \%$ are members of a private health insurance (German Federation of Private Health Insurers).
}

days, which are under-recorded in this series, are possibly offset by non-compulsorily insured persons (employees not covered by the agreed pay scale, civil servants, and marginal part-time employees) with their typically lower levels of lost working hours. Cases in which people resume work while still certified unfit for work by a physician have a similar effect.

However, the reference of sick leave statistics to a single date creates problems if the first day of the month is on a weekend or a floating public holiday. Then, the number of sick leaves is well below the level found for normal working days, and artificial fluctuations both in the original as well as in the seasonally adjusted time series occur. To avoid such problems we adjust the time-series of sick leave using usual weekday and holiday effects and modify the series to fit the seasonal patterns reported by the major statutory health insurers AOK and BKK. For these calculations, we make use of statistical state space methods, which allow us to separate weekday and holiday effects from seasonal and other fluctuations (cf. Wanger et al. 2014).

Since the monthly statistics of the Federal Ministry of Health are not broken down into economic sectors, the annual health reports of AOK and BKK (cf. Knieps and Pfaff 2014, Meyer et al. 2014) are used to compute the sectorspecific figures in a top-down approach. The annual health reports indicate days of sick leave for different economic branches, which are adjusted to gain representativeness for all employees subject to social insurance contributions.

\subsection{Definitive and transitory overtime hours}

Overtime work is classified into definitive and transitory overtime hours (cf. Zapf 2012). Definitive overtime work comprises paid and unpaid overtime hours (cf. Sect. 3.6.1), both of which extend the working time of an employee without an inherent balancing mechanism. In contrast, transitory overtime hours (cf. Sect. 3.6.2) are additional hours worked that can be used up later by employees, so that they can take time off in lieu of overtime. Transitory overtime hours only change the allocation of the working time, while the number of working hours over a longer reference period is unaffected (cf. Kohler and Reyher 1988; BundesmannJansen et al. 2000). During the last years, transitory overtime hours got more important. This growing importance can also be attributed to the increasing deployment of working-time accounts, where transitory overtime hours can be accumulated (cf. Zapf 2012).

\subsubsection{Paid and unpaid overtime}

Paid and unpaid overtime hours are calculated mainly on the basis of the yearly GSOEP while also the Microcensus enters the accounts for computations on recent years. The 
GSOEP contains information about the number of weekly overtime hours and its compensation form (compensated with time-off; partly paid, partly compensated with timeoff; paid; not compensated at all). On that basis, the number of annual paid and unpaid overtime hours can be calculated. Problems arise due to the assignment of partly paid overtime hours. Since 2001, these overtime hours can be assigned through information by the additional question of the number of paid overtime hours last month. With this information the otherwise undetermined cases of partly paid overtime hours are made unambiguous, while the resulting fraction of paid hours among the ambiguous cases is extrapolated to previous years. Certain groups of employees (marginally employed, apprentices and employees with zero working hours, e.g., on parental leave) do not work paid overtime according to their contract, which we take into account in the calculations.

Since 2010, the Microcensus regularly contains questions on paid and unpaid overtime hours. Average figures can be calculated on a quarterly basis as the survey is carried out during the whole year and enter the accounts through a statistical model-based approach. The model also allows us to take into consideration several related surveys and other indicators containing information on overtime fluctuation. They improve the estimates especially at the current edge, where the main survey sources are not yet available; see Weigand et al. (2015). One major additional indicator for the calculation of overtime hours is the Ifo Business Survey, where establishments indicate whether employees work overtime at the moment, and whether overtime hours are unusually high. Additionally, the GDP, new orders for all manufacturing industries, the industrial production index, the number of persons in employment, registered unemployment, compensation for employees, the willingness to buy from the GfK, the business expectations and situation from the Ifo Institute, as well as the Ifo employment barometer are integrated in the calculations. To obtain the number of paid overtime hours separately for industries, West and East Germany and for full-time and part-time employees, data of the Structure of the Earnings Survey of the Federal Statistical Office are used additionally to the GSOEP and the Microcensus.

Despite the efforts to make overtime statistics as precise and timely as possible, due to the impact of GSOEP survey errors on the final estimate and limited intra-year information, these components are less accurate as compared to other components of the AZR, and hence the estimates should be used in view of this uncertainty.

\subsubsection{Working-time accounts}

As outlined above, a second major cyclical component of hours worked is due to changing hours on working-time accounts. Deviations from regular or collectively agreed working hours lead to savings (credits) or deficits (debits) on these accounts, which have to be balanced during a certain period of time (cf. Seifert 1998, 2001).

Although different datasets contain information about the distribution of working-time accounts among establishments and employees, there exist few data sources on the accumulation and reduction of working hours on these accounts. Especially, regularly surveyed information about working hours on working-time accounts is very sparse.

As mentioned above, the GSOEP comprises information about overtime hours which are compensated with timeoff later. These can be viewed as the accumulation of time credits on working-time accounts, as the compensation with time-off needs a formal or informal documentation and recording of the additional hours worked. However, until 2014 where an according question has been introduced, there is no information on the reduction of time credits, i. e., the compensation of additionally hours worked with time-off. Thus, an estimation of the net flows on working-time accounts cannot be conducted solely on basis of the GSOEP. For this reason, we draw additional information from the Microcensus. Here, survey participants are asked about their regular working time, the actual working hours in the last week before the survey and the main reason why they worked more or less than the regular working time. One reason for fewer working hours is a compensation for additional hours worked (e.g. flexible working hours), while a reason for additional hours worked is the accumulation of time credits or reduction of time deficits. These variables are the basis for the estimation of time series models for the changes of balances on working-time accounts.

The accuracy of the level of account flows obtained from the Microcensus is questionable, since working-time account flows are only captured if they are the main reason for varying working hours, and hence the flows are likely to be biased downwards. To avoid this problem, we rather extract the percentage transitory fluctuations of these flows around their long-term trends from the Microcensus. The longer-term trends in the gross inflows on and outflows from working-time accounts are theoretically identical, so that we identify these trends from the GSOEP data on inflows only. The trend is then combined with the cycles to obtain gross in- and outflows and the net flow on workingtime accounts per period is obtained from the difference between the latter; see Weigand et al. (2015) for more details. To assess the overall accuracy of the components, note that possible survey errors are complemented by model uncertainties. The latter may be larger than for other components, but seem unavoidable given the current state of data available on that topic. 


\subsection{Short-time work}

Short-time work leads to a temporary reduction of the actual hours worked. It is used to relief the pressure from enterprises by reducing the payroll costs during temporary times of low business activity (cf. Crimmann et al. 2010). Since the rearrangement of short-time work in 2007, the German system distinguishes three kinds of short-time work: besides short-time work for economic reasons and seasonal short-time work, the so-called "transfer-short-time work" is possible for firms which face a permanent loss of employment due to restructuring measures at the firm level.

When calculating hours lost due to short-time work, data published by the BA are considered. The lost working hours per short-time worker are calculated from the statistically documented percentage loss, assuming that the percentage loss of working hours per short-time worker is not different between part-time and full-time workers.

Until 2006, a "bad weather-component" was also part of the AZR. The number of lost hours and the affected employees due to bad weather were recorded to the extent that the BA paid benefits until 2006. The loss of working hours through bad weather was by definition only possible in the construction sector. In 2007 the bad weather compensation (Winterbauförderung) was replaced by the seasonal short time working allowance (see above). Therefore the time-series on working hours lost due to bad weather end in 2006 (see Appendix A, Table A.1) and are captured in line with the total short time working allowance component from 2007 on.

\subsection{Strikes and lock-outs}

After failed negotiations for new collective agreements, usually strikes are taking place. However, they are quite rare as centralized agreements prevail in the German economy. Lockouts are defined as the refusal of an employer to give the employee access to their workplace and refusal to pay wage at the same time during a strike. In Germany lock-outs are also rarely used.

The Strike Statistics ${ }^{9}$ of the BA provides sufficiently deep economic and temporal breakdowns for the strikes and lockouts and can be directly converted into volumes of hours lost using the collectively or customary hours worked. In the Strike Statistics labour disputes are only shown if they are lasting longer than one day and at least 10 employees are involved (affected) or generating a loss of more than 100 working days. All other disputes are classified as small claims (Bagatellstreitigkeiten) and are listed for information

\footnotetext{
9 This statistic of the BA show companies and employees affected by
} strikes and lockouts as well as the days lost. only. As far as they are reported to the BA they are also considered in the calculation.

\subsection{Adjustments for differences in the calendar}

As described in Sect. 3.2, differences in the potential number of working days occur depending on whether public holidays are on weekdays or on whether the current year is a leap year. The deviations from the average number of working days over many years are compensated to some extent by adjustments to overtime and working-time accounts (Deutsche Bundesbank 2012). However, at least a portion of the effects on working time is not covered by the latter. An additional weekend day or public holiday does not lead to zero working hours, as a certain amount of labour is indispensable and is either done even on holidays or weekends, or gives rise to shorter breaks and other unobserved flexibility in working time. This is mirrored by economic output which does not change proportionally to the development of working days: an increase in the number of working days by one per cent leads on average to a $0.3 \%$ increase of total economic production (Deutsche Bundesbank 2012).

In the components discussed so far, the changing number of working days leads to a proportional change in the volume of work. This would result in an excessively volatile productivity development caused by calendar-effects. Therefore, working time elasticities specific to economic branches are needed to approximate the correlation between a change of number of working days and a change of labour volume. These working-time elasticities should measure by how many hours the annual hours worked change when more or less working days are available, and hence the latter are not included in annual hours worked one-to-one. As suitable data for estimating these effects are not available, we take the elasticities to correspond to working days elasticities of production calculated by the German Bundesbank. These elasticities indicate the percentage by which the production increases if the potential working hours are extended by one per cent due to (the fraction of) an additional working day. The estimated working day effect reflects the difference of production carried out at a normal work day and the production carried out at a weekend day.

For determining the compensatory hours due to the elasticities being smaller than one, we first calculate the longterm working time, which is the product of the average of potential working days by quarters over the last 20 years and the collectively agreed working time in the given year. By subtracting the collectively agreed working hours of the year from these long-term annual hours we obtain a deviation in hours from the long-term average. These additional or reduced hours compared to the long-term average are 
not fully taken into account in the annual hours worked, but only a fraction given by the working days elasticities. The remaining hours are the compensatory hours taken into account within the component "adjustment for differences in the calendar". This procedure is carried out sector-specific and for full- and part-time employees separately.

\subsection{Secondary jobs}

Besides the time worked by employees at their main (or only) job also the volume of work from second or third jobs is taken into account. Up to 2003, the only source for the number of employees and average hours worked in secondary jobs was the Microcensus. Since then, it is also possible to use the sector-specific BA statistics on secondary employment of employees subject to social insurance contributions. These additional information in the Employment Statistics of the BA are the result of legal changes regarding secondary employment ${ }^{10}$.

Since the Employment Statistics of the BA provide no information on the duration or length of working hours, we use basic information from the Microcensus to obtain the average weekly hours worked by employees in the side job. The ratio of the average number of hours worked by side employees to the average number of hours worked by fulltime employees is calculated for each industry.

\subsection{Hours worked by self-employed and unpaid family workers}

In addition to the hours worked by dependent employees, the hours worked by self-employed and unpaid family workers are considered in the measurement concept. Since patterns of hours worked by self-employed persons themselves and their unpaid family members differ fundamentally, both groups are treated separately in the AZR. The calculations of hours worked differ methodologically from those for employees because a large part of the components of hours worked are not relevant here (see Sect. 2.1).

The most important source for average hours worked of self-employed and unpaid family workers is the Microcensus, collecting the hours (normally) worked per calendar week. It is assumed that the hours worked are distributed evenly over the whole year. The only exception is the agriculture and forestry sector, where working hours outside the

\footnotetext{
${ }_{10}$ Until 1999, marginal secondary employment with a regular working week of $15 \mathrm{~h}$ or less was exempt from social insurance contributions. This changed in 1999: marginal secondary employment was completely liable to tax and social insurance contributions. Then, from 2003 on, marginal secondary employment besides a main job has become more appealing again, because no social insurance contributions are paid when the income does not exceed an income limit. This income limit currently amounts to $450 €$.
}

high season is presumed to be lower. Thus, we use a $30 \%$ lower working time for the first and fourth quarter. ${ }^{11}$

According to the GSOEP (cf. Saborowski et al. 2004 and own calculations), self-employed persons only take two thirds of the number of holidays as compared to employees, which we use to estimate the holiday leave for self-employed persons of each specific industry. For the seasonal distribution of leave, we assume that there is no difference between self-employed persons and employees. For the former, also the extent of sick leave is substantially lower than for employees. However, there are considerable variations in the results of sick leave days for self-employed persons. The statistics of statutory health insurance companies indicate that the number of sick leave days is between one third and one half of those of employees (cf. Küsgens et al. 2002), while the Employment Surveys of the Federal Institute for Vocational Education and Training (BIBB) and the Federal Institute for Occupational Safety and Health (BAuA) indicate values between one third and two thirds. On the basis of these analyses we assume half the sick leave rate of employees. Based on results of the Microcensus, the labour volume performed by persons who are selfemployed in a second activity is also considered here.

\section{Selected results from the AZR}

In this section, we present selected results of the AZR. We aim to illustrate the overall development of different groups of employment, of hours worked and of the volume of work in Germany during the last 25 years, as well as the influence of the different components on that longer-term development. Moreover, emphasis is given to the business cycle properties of hours worked in Germany and to the development in the 2008/09 financial and economic crisis. Detailed results referring to the data version of March 2015 can be found in Table A.1 (see Appendix A).

\subsection{Employment by status}

In 2014 around 42.7 mio. persons were in employment, which is a $10 \%$ increase as compared to 1991 (Fig. 2).

\footnotetext{
11 Before changing to a continuous questioning in 2005, the German Labour Force Survey was carried out in the work-intensive second quarter. Thus, by using the mentioned adjustment factors, the otherwise extremely high annual averages for working hours in the agriculture sector are made more plausible in relation to other surveys. In a future revision of the AZR, the seasonal structure of working hours will be estimated based on the available intrayear data. The current assumptions influence the overall level of hours worked and labour volume, but not the seasonally adjusted quarterly changes. E. g., in 2014a $10 \%$ lower working time in the first und fourth quarter in agriculture led on average to $0.4 \%$ lower hours worked and volume of work for self-employed persons.
} 


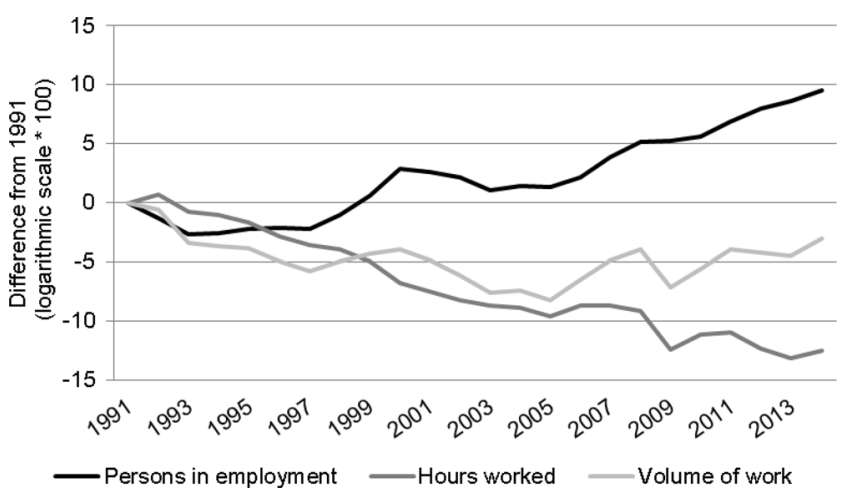

Fig. 2 Development of employment, hours worked and volume of work; annual averages 1991-2014. (IAB Working Time Measurement Concept, Federal Statistical Office and own calculations)

Behind the increasing number of persons in employment there are different developments of full-time and part-time employment as well as the number of self-employed persons and family workers (Figs. 3, 4 and 5). In 2014, the number of employees was around 3 mio. persons higher than in 1991 (Table A.1). However, the so-called "normal employment relationship" (Normalarbeitsverhältnis) determines the development of employment to a fewer extent as the number of full-time employees decreased (Fig. 6 and 4). In contrast, contracts with less working hours are more and more widespread, as the number of part-time workers has more than doubled (Table A.1). Since 2006, however, also the number of full-time employees increased slightly - with the exception of a decline due to the financial and economic crisis in 2008/09. The contrary developments of full-time and part-time employment led to an increasing part-time rate, which rose from $17.9 \%$ in 1991 to $38.6 \%$ in 2014 (Fig. 6). From this rate, 15 percentage points can be attributed to persons in marginal employment.

In 2014, around 4.4 mio. persons were self-employed or family workers. In comparison to 1991 their number increased by $24 \%$ (Fig. 5). The share of family workers within this group was around $4 \%$ in 2014, with their importance decreasing rapidly since 1991 (12\%), especially due to the strong decline in the agricultural sector.

The increase of self-employed and family workers since 2002 can be mainly attributed to the increase of self-employed workers without employees (Solo-Selbstständige). In 2014, their share was $56 \%$. The increase of self-employed workers without employees is supported by government aid. It can be assumed that one part of this increase can be attributed to the intensified use of labour market policy instruments, like interim payment (Überbrückungsgeld) and grants for business start-ups (Existenzgründungszuschuss). Since 2006, these labour market policy instruments are combined as start-up subsidies (Gründungszuschuss). However, since 2011, the financial support of the BA for self-employed workers declined considerably.

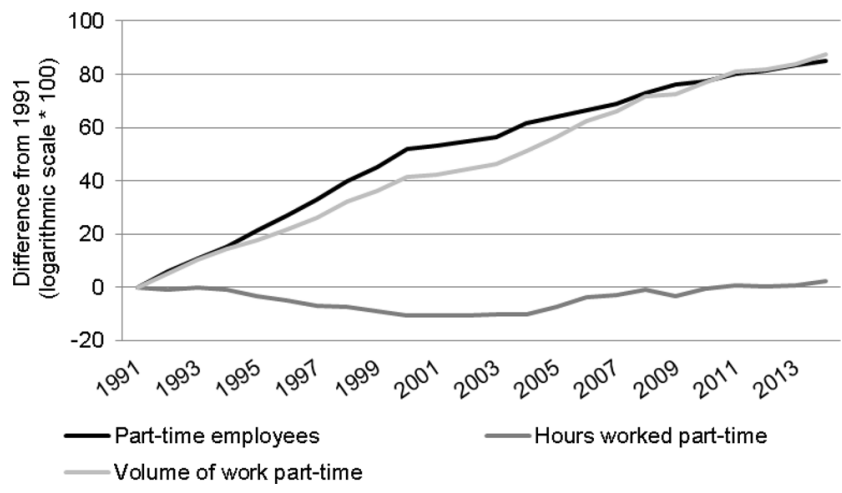

Fig. 3 Development of part-time employees, hours worked and volume of work; annual averages 1991-2014. (IAB Working Time Measurement Concept, Federal Statistical Office and own calculations)

\subsection{Working time}

\subsubsection{Components of hours worked}

In this section, results for the single working time components are presented, which are greatly affecting the hours worked and the labour volume (see Table A.1). The effects of the different components vary a lot and changes in their importance have different impacts on the amount of hours worked and the volume of work. The components bad weather and labour disputes are of minor importance for the overall economy and are consequently left from our review of results here.

Of major importance is the collectively agreed or customary weekly working hours of employees. It is the reference point for all working time agreements beyond full-time employment. In 2004, the collectively agreed or customary weekly working hours for full-time employees reached its lowest level with $37.9 \mathrm{~h}$ on average, and increased slightly since then. Due to reductions during the financial and economic crisis (cf. Bogedan et al. 2009), however, the collectively agreed or customary weekly working hours declined temporarily.

The gap between collectively agreed or customary weekly working hours in East and West Germany is still remarkable $(0.8 \mathrm{~h})$, but it has already declined considerably since 1991, when the difference was $2.4 \mathrm{~h}$. There are also noteworthy differences between industries. In public service and in the construction industry the collectively agreed or customary weekly working hours increased, whereas it decreased in non-public parts of the service sector and in the manufacturing industry.

On average, the number of annual paid holidays (and other related release times) is 31 days per employee and year. Until the mid-1990s the claim for paid holidays mainly increased due to the adaption of the number of collectively agreed regular holidays in East Germany to West German conditions. Besides the number of holidays, 


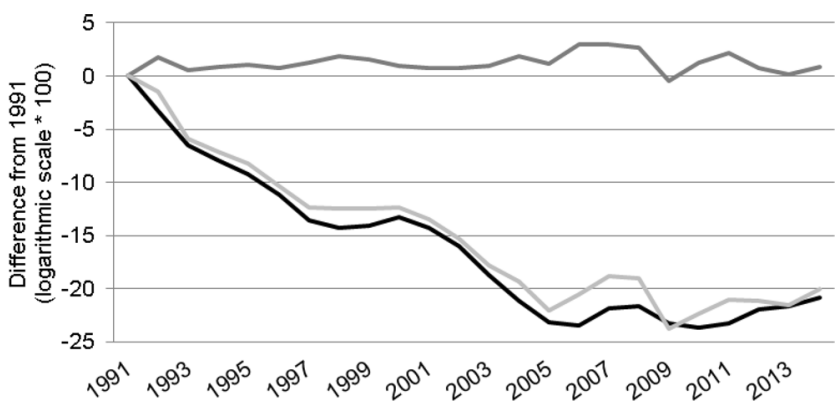

_Full-time employees _- Hours worked full-time — Volume of work full-time

Fig. 4 Development of full-time employees, hours worked and volume of work; annual averages 1991-2014. (IAB Working Time Measurement Concept, Federal Statistical Office and own calculations)

also absences from work due to illness decrease the annual working time. Until 2007, sick leave in hours worked decreased to a historically low level of $49 \mathrm{~h}$ per employee and since then it increased again. The long-term decline of sick leave can be partly attributed to structural shifts in employment to industries and occupations with fewer physical burdens for employees. Additionally, it can also be explained by changes in behaviour on the establishment side, like e. g. better safety regulations and health management (cf. Knieps and Pfaff 2014).

During the last two decades the importance of paid overtime decreased sharply. In 1991, the volume of paid overtime hours was $1.6 \mathrm{bn}$. h (Fig. 7), while it declined to $0.8 \mathrm{bn}$. $\mathrm{h}$ in 2014. In 2009, the volume of paid overtime work reached its lowest level due to the crisis. The decline of paid overtime hours and the volume of paid overtime can be explained by several reasons: On the one hand, groups of employees who traditionally work less paid overtime hours gain importance, e.g., women. Likewise, sectors in which paid overtime work is less widespread get more important, e. g., the service sector. On the other hand, flexible working time arrangements like working-time accounts are increasingly popular. In 2014 , the volume of unpaid overtime hours was $1.1 \mathrm{bn}$. h (Fig. 7) and hence higher than the volume of paid overtime hours. Unpaid overtime hours are mainly worked by employees with a higher qualification level and by employees with managerial responsibility (cf. Weber et al. 2014). Employees supply unpaid overtime e. g. to get promotions and pay rises (cf. Anger 2006).

As was explained in Sect. 3.6.2, one major part of additional hours worked can be accumulated on working-time accounts and used up later by working fewer hours. Due to the financial and economic crisis, the number of accumulated hours on working-time accounts was reduced by $9.1 \mathrm{~h}$ per employee over the whole economy. In 2009, also the number of short-time workers sharply increased to $1.1 \mathrm{mio}$. on average (Fig. 8). The intensive use of short-time work during the crisis can partly be explained by the eased uti-

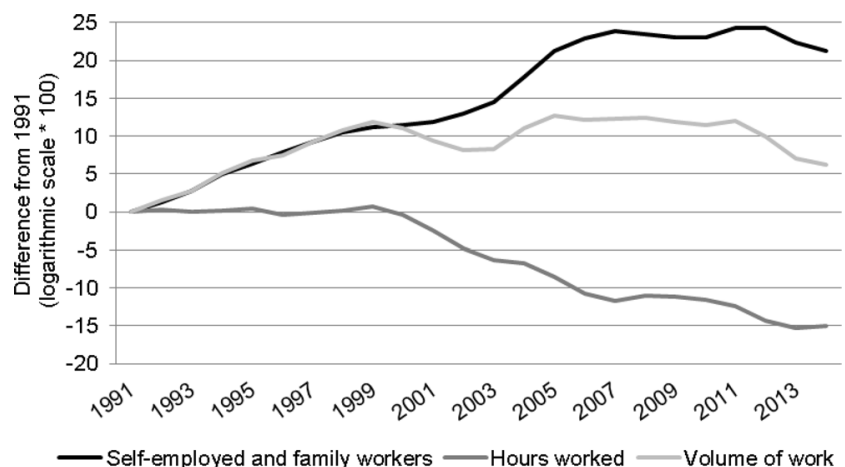

Fig. 5 Development of self-employment, hours worked and volume of work; annual averages 1991-2014. (IAB Working Time Measurement Concept, Federal Statistical Office and own calculations)

lization. The government extended the period to use shorttime work and employers were relieved from social insurance contributions. Based on all employees, the average loss was $12.5 \mathrm{~h}$ per employee in 2009. At the beginning of the 1990s short-time work was also used intensively due to the German reunification.

Among the components of hours worked, the importance of secondary jobs increased. From 1991 to 2014, the number of persons with a secondary job shot up from 0.9 to 2.8 mio. people, with the share of persons with secondary job increasing to $7.2 \%$ (1991: $2.5 \%$ ). Only from 2000 to 2002 the number of persons with a secondary job decreased due to the introduction of compulsory insurance. In 2003, the new regulations of marginal employment promoted the increase of secondary jobs as the legal framework allows an additional income of $450 €$ largely exempted from taxation and social security. Since 1991, the effect of secondary jobs on hours worked has nearly doubled from 8.9 to $17.0 \mathrm{~h}$ in 2014 per employee. The reasons for a secondary job are manifold. Some persons are voluntarily searching for flexible forms of employment, while others are in need of additional income. However, the majority of secondary jobs is characterized by a high qualification level (see e. g. Brenke 2009; Heineck 2009). Additionally, Schmidt and Voss (2014) show that employees who would like to work longer in their main job and women with a lower income are more likely to perform a secondary job.

\subsubsection{Hours worked}

Considering all components, the average annual working time per employee is calculated which is strongly determined by the relationship between full-time and part-time employees and their internal structure: Regular part-time employees work around half of the working hours of fulltime employees, whereas persons in marginal employment only have around a quarter of the working time of a fulltime employee. Changes in this internal structure can have 


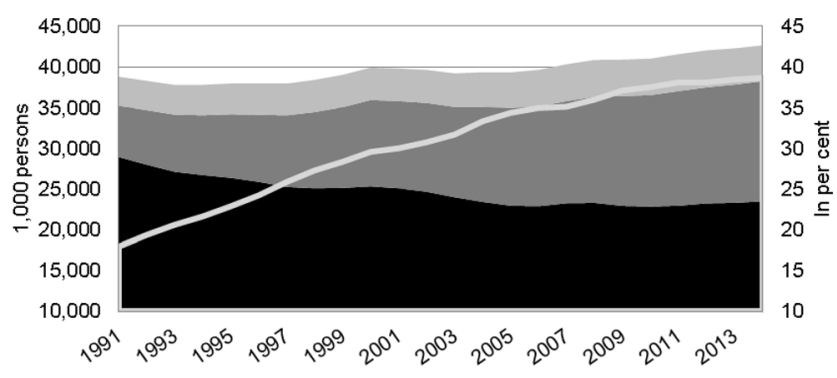

$\square$ Self-employed and family workers (left axis) $\square$ Part-time employees (left axis)

- Full-time employees (left axis) Part-time share (right axis)

Fig. 6 Development of employment and the part-time share; annual averages 1991-2014. (IAB Working Time Measurement Concept, Federal Statistical Office and own calculations)

major consequences on the average hours worked by all part-time employees and also on the average hours worked by all employees (in full-time and part-time). As a consequence, a high number of employees do not necessarily lead to a higher overall labour volume if the structure of employees is changing.

In 2014, the average annual working time of full-time employees was $1657 \mathrm{~h}$ and hence slightly higher than in 1991 (1643 h), when short-time work was highly used (Fig. 4 and 9). The average annual working time of parttime employees was also higher in 2014 as compared to 1991 (Fig. 3 and 9). At the end of the 1990s and at the beginning of the 2000s it mainly decreased due to the increasing importance of marginal employment. That increasing importance can be partly attributed to the HartzII reforms ${ }^{12}$ which took effect in 2003. The ratio of annual working hours of part-time employees to the annual working hours of full-time employees decreased to $36.5 \%$ until 2004. Since then this ratio increased again and in 2014 it was $41.8 \%$.

Due to the enormous increase of the part-time rate the average hours worked of all employees (without secondary jobs) decreased from $1470 \mathrm{~h}$ in 1991 to $1285 \mathrm{~h}$ in 2014 $(-185 \mathrm{~h}$ or $12.6 \%)$. If the average working time of all employees is compared to the average working time of fulltime employees, then the increasing importance of the parttime effect becomes evident. From 1991 to 2014, the parttime effect increased from 173 to $372 \mathrm{~h}$ (Fig. 9). ${ }^{13}$ As a consequence, the decline of the average annual hours worked of all employees in the last 25 years is not the result of pure working time reductions, but rather results from structural changes in employment.

12 More information about the Hartz reforms in Germany is given by Möller (2014).

13 The part-time effect is calculated by subtracting the working time of all employees (in full-time and part-time) from the working time of full-time employees.
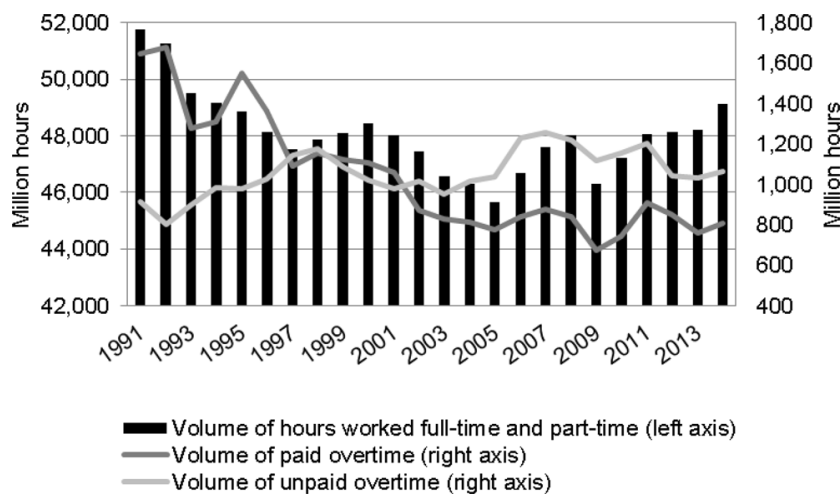

Fig. 7 Volume of work and volume of (un-)paid overtime work; annual averages 1991-2014. (IAB Working Time Measurement Concept)

The working time of self-employed workers and family workers exceeds the annual hours worked of employees to a great extent. In 2014, self-employed and family workers performed on average $1973 \mathrm{~h}$. In the 1990s their annual working time was on average $320 \mathrm{~h}$ higher, but since 2001 it declines. This decline is due to the increasing share of self-employed workers without employees, with one third of them working part-time. As a result the part-time rate among self-employed workers strongly increased. One reason for this increase is the larger use of subsidized founding until 2011. Recent studies show that the working time in those newly founded establishments is lower than among traditional self-employed workers, and that self-employment in part-time seemed to be realised with this instrument (cf. Caliendo et al. 2009). Other studies also show that the foundation process in Germany seems to change from selfemployment in full-time to part-time self-employment (cf. Brenke 2013).

The annual hours worked of all persons in employment consists of the annual working time of employees and the annual working time of self-employed and family workers. The development of the annual working time of all employed persons is mainly driven by the annual working time of employees. In 2014, the annual working time of all employed persons was $1371 \mathrm{~h}$ and considerably lower as compared to 1991 (1554 h).

\subsection{Volume of work}

As the relevant labour input measure of the economy, the volume of work of employees is the product of the number of employees and their annual working time. In 2014, the labour volume of employees was $49.8 \mathrm{bn}$. h, which is 2.3 bn. h or $4.4 \%$ lower than in 1991 (Fig. 10). This decrease results from the period before 2005 and especially from the 1990s, while since 2006 the volume of work is increasing again with a short interruption during the financial and economic crisis. However, the labour volume of full- 


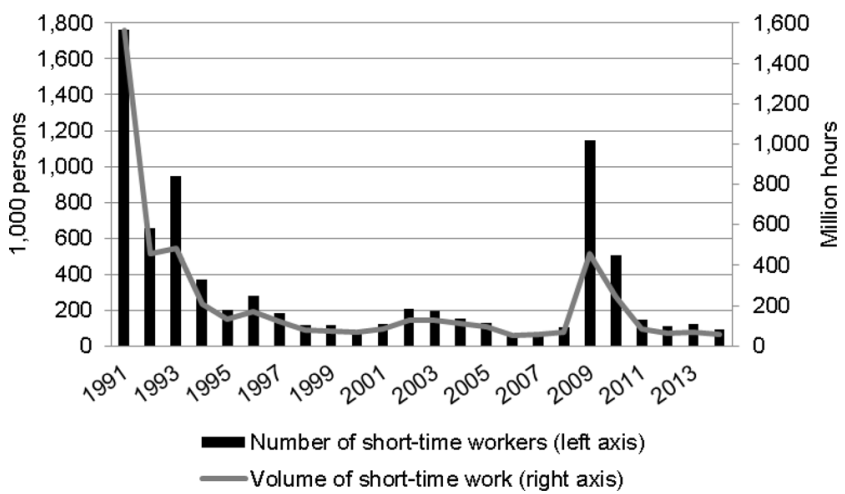

Fig. 8 Number of short-time workers and overall volume of shorttime work; annual averages 1991-2014. (IAB Working Time Measurement Concept)

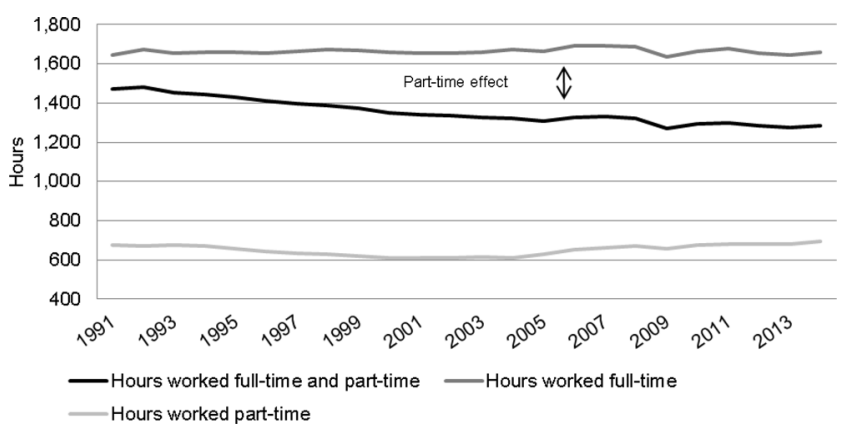

Fig. 9 Development of hours worked; annual averages 1991-2014. (IAB Working Time Measurement Concept)

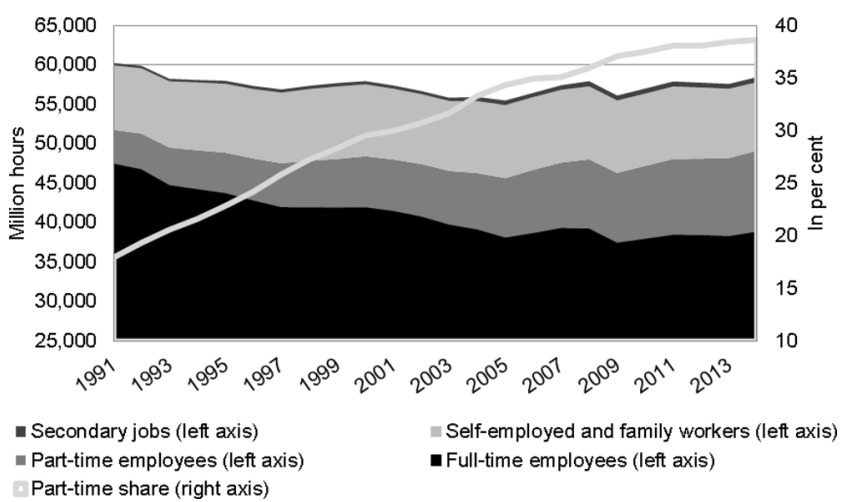

Fig. 10 Development of volume of work and the part-time share; annual averages 1991-2014. (IAB Working Time Measurement Concept)

time employees decreased by 8.6 bn. h $(18.1 \%)$, whereas that of part-time employees more than doubled: In 2014, it was $10.2 \mathrm{bn}$. $\mathrm{h}$ and made $20.6 \%$ of the overall volume of work of all employees (Fig. 3 and 4). These results reflect the overall development in gainful employment: Compared to 1991a lower volume of work is distributed among more employees.

In the 1990s, the development of the labour volume of self-employed workers and family workers was mainly driven by the changes of their number, whereas the actual annual working time mainly remained constant (Fig. 5). Since 1991, the volume of work increased by $0.5 \mathrm{bn}$. h or $6.4 \%$, respectively, to $8.7 \mathrm{bn}$. h This corresponds to a share of $14.9 \%$ of the overall volume of work in the German economy.

Between 1991 and 2014, the labour volume of all persons in employment decreased by $3.0 \%$. In 2014 , it made up 58.5 bn. h as compared to $60.3 \mathrm{bn}$. h in 1991 (Fig. 2 and 10). As mentioned earlier, this decline results from the decreasing number of full-time employees until the year 2005. The decreasing volume of work of full-time employees (Fig. 4 and 10) could only be partly compensated by the increasing volume of work of part-time employees (Fig. 3 and 10) and the volume of work of self-employed workers and family workers (Fig. 5 and 10).

\subsection{Cyclical behaviour of labour input and productivity}

We conduct a cyclical analysis of working hours and related measures in Germany. More precisely, we investigate the fluctuations of seasonally adjusted per capita labour input and productivity around their long-run trends, assessing the size of such fluctuations as well as their co-movements with real GDP and among each other. Summary statistics of this kind are of vital importance for the empirical assessment and calibration of business cycle models. At the same time, they allow cross-country comparisons of cyclical labour market behaviour and an identification of changes in the dynamic properties. To make the outcomes comparable with previous studies, we use the method of Hodrick and Prescott (1997) to subtract the trend from the logarithmic series. The standard smoothing parameter for quarterly data, $\lambda=1600$, is applied. The results of Ohanian and Raffo (2012) serve as a benchmark for international comparisons. There, the AZR data before the major revision enter the assessments, which are mostly aggregated over EU countries.

Table 4 gives summary results for the series of real GDP, labour volume $(\mathrm{H})$, total persons employed (TE), hours worked per person employed (H/TE), productivity per hour $(\mathrm{GDP} / \mathrm{H})$ and productivity based on persons employed (GDP/TE) for quarterly data from 1991Q1 to 2014Q4. The main diagonal shows the standard deviation of the trend adjusted series relative to the volatility of GDP.

The relative standard deviations reveal that labour input as measured by the volume of hours worked is more volatile than the employment-based figure. The cyclical fluctuation is relatively small in an international comparison, where the average is about one, at least in the sample from 1985 to 2007; see Ohanian and Raffo (2012; Table 4). As for other comparisons, differences between the countries may be due to structural differences, differences in the statistical system, or simply sampling errors in the estimates, which 
Table 4 Cyclical volatility relative to GDP (main diagonal) and correlations (off diagonal), 1991Q1-2014Q4. (IAB Working Time Measurement Concept, Federal Statistical Office and own calculations)

\begin{tabular}{lllllll}
\hline- & GDP & H & TE & H/TE & GDP/H & GDP/TE \\
\hline GDP & 1.00 & - & - & - & - & - \\
$\mathrm{H}$ & 0.84 & 0.69 & - & - & - & - \\
TE & 0.59 & 0.71 & 0.52 & - & - & - \\
H/TE & 0.50 & 0.62 & -0.09 & 0.49 & - & - \\
GDP/H & 0.73 & 0.26 & 0.16 & 0.18 & 0.54 & - \\
GDP/TE & 0.84 & 0.58 & 0.08 & 0.71 & 0.81 & 0.80 \\
\hline
\end{tabular}

also significantly contribute to the outcomes in each of the countries.

We next assess the correlation between the cyclical components. We do not consider lags of the variables to ensure comparability to international benchmark studies such as Ohanian and Raffo (2012) and to keep the presentation clear. The labour input is strongly pro-cyclical in Germany, with a cyclical correlation of 0.84 with GDP. This is the result from both persons employed and hours per person being positively associated with output. The latter components are hardly correlated with each other, which correspond to the results for other OECD and particularly European countries; see Figure 3 of Ohanian and Raffo (2012).

The difference between the hours-based and employment-based labour input is mirrored by a difference between the productivity measures, where the latter have a stronger cyclicality and output co-movement than hourly productivity. The correlation between productivity and labour input is relatively weak, both measured in terms of hours and in terms of employment. This pattern was observed also in other countries and has been interpreted as evidence against a single source of business cycle fluctuations. For our German dataset, the correlations are 0.26 and 0.08 , respectively. Note, however, that measurement errors in the labour input $\mathrm{H}$, which are described throughout this paper, lead to a downward bias of Corr $(\mathrm{GDP} / \mathrm{H}, \mathrm{H})$, while errors in the measurement of GDP have the same effect. Due to this so-called division bias (see Borjas 1980) the low correlation in Germany and also throughout the international comparisons should be interpreted with care. ${ }^{14}$

Overall, considering the labour volume in hours instead of employment as a proxy for labour input yields a significantly different view on labour market fluctuations at business cycle frequencies.

14 We thank an anonymous referee for pointing this out.

\subsection{The development of hours worked during the 2008/09 financial and economic crisis}

In 2008/09, the German economy was severely hit by the global financial and economic crisis. GDP shrank by $5.6 \%$ in 2009. Economic forecasters predicted an increase in unemployment of more than 1.4 mio. people between 2008 and 2010. However, the repercussions of the economic slump for the labour market were quite modest and in 2009 total employment even increased slightly (cf. Herzog-Stein and Zapf 2014). This development was so unexpected that it was often described as the "German Labour Market Miracle" (cf. Möller 2009; Burda and Hunt 2011). In the industrial sector jobs were still lost, but to a lesser extent than expected. At the same time part-time employment increased and contributed to the overall increase of employment.

The remarkable development of the German labour market during the crisis can be partly attributed to the establishments' extensive use of internal flexibility and strategies of labour hoarding to protect and retain firm-specific human capital. To achieve a hoarding of labour, establishments can either reduce working hours of employees or decrease work intensity and hence labour productivity (cf. HerzogStein and Zapf 2014). The results from the AZR show that working time reductions played an important role. In 2009 , the average annual working time of employees was reduced by $50.4 \mathrm{~h}$ or $3.8 \%$ as compared to 2008 (Fig. 11). A notable adjustment took place by temporary reductions in standard working hours within collective agreements or company-level pacts (betriebliche Bündnisse). These are shown in Fig. 11 under the component "weekly working hours" $(-12.6 \mathrm{~h}$ of the overall decrease), which gives the hypothetical change of average collectively agreed/customary weekly working hours of all employees if the composition of the workforce into full- and part-time employees were held constant. In addition to short-time work $(-10.6 \mathrm{~h})$, reductions in paid overtime $(-4.7 \mathrm{~h})$ and unpaid overtime $(-2.8 \mathrm{~h})$, the reductions on working-time accounts played an important role, too, as compared to earlier recessions $(-11.4 \mathrm{~h})$. Also the part-time effect, which is the impact of changes in the workforce composition on working hours, contributed to the decrease of the annual working time $(-10.9 \mathrm{~h})$, whereas holidays led to an extension $(+4.5 \mathrm{~h})$. This positive contribution of holidays to the development of the working time in 2009 can be explained by the fact that

\footnotetext{
15 More detailed analyses concerning the development of the German labour market during the crisis as well as the important role of working time reductions on basis of the results of the AZR can also be found in Möller (2009), Dietz et al. (2010), Gartner and Klinger (2010), Walwei (2010) and Burda and Hunt (2011).
} 


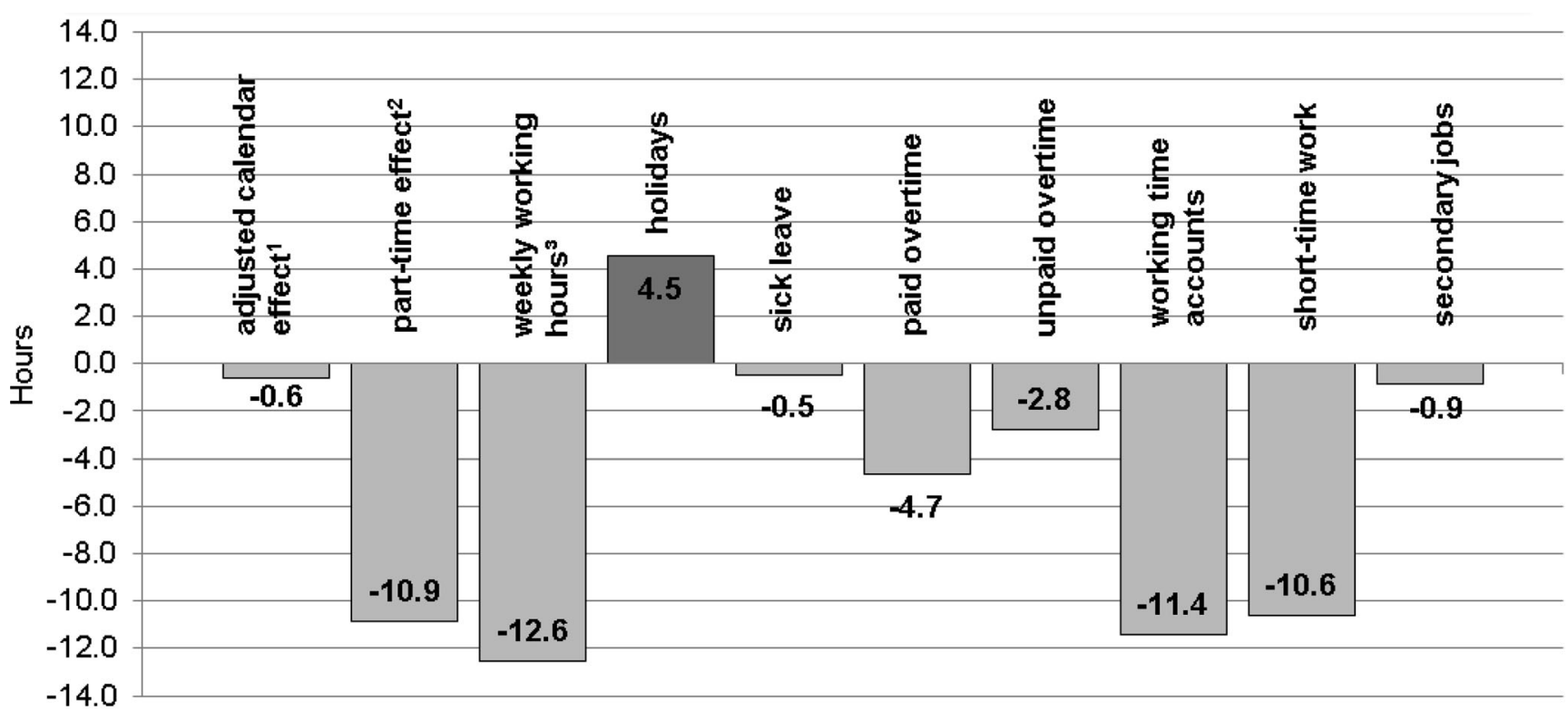

Note: Not every contribution of the components can be directly derived from Table 5 (see Appendix A).

1 Adjusted calendar effect $=$ Effect of working days plus adjustments for differences in the calendar

2 Part-time effect $=$ Impact of changes in workforce composition on working hours

${ }^{3}$ Weekly working hours $=$ Effect of collectively agreed/customary working hours when composition into full-time and part-time employees is held constant

Fig. 11 Contribution of the working time components to the development of hours worked by employees in 2009, changes against previous year in hours. (IAB Working Time Measurement Concept)

employees partially used up holidays for that year already in 2008 when the crisis began. ${ }^{15}$

\section{Summary}

Measuring hours actually worked in Germany and their single components is a complex task. This is mirrored by the AZR which we outlined in this article. The results cover time series on hours worked and the volume of work at an aggregate level, but also allows for discrimination along several criteria such as groups of employed persons and economic sectors. The componentwise approach which allows us to identify, among others, collective, calendar, personal and cyclical influences is a particularly effective and informative way of collecting and presenting statistical information on this topic.

The availability of high-quality and detailed data on hours worked in Germany enhances empirical research in several fields, such as macroeconomics and sociology. The current paper is meant to spur further scientific work by both providing a comprehensive summary on the data product and an outline of elementary results.
Meeting the multiple demands of data users also requires a permanent process of revision in the AZR. Recently, changes in data availability, ongoing trends in the world of work, legal changes in definitions and concepts, but also an increasing methodological toolkit have promoted innovations in the measurement. Communicating these progresses we also aim at advancing the discussion among official statisticians concerned with national accounts and related data products.

The increasing flexibility of working (time) arrangements is still imposing challenges for a proper measurement of hours worked. Gathering additional information regarding temporary establishment-specific instruments such as working-time corridors for parts of a business, but also on flexible individual arrangements such as trust-based working time, sabbaticals or home office appears especially worthwhile. Future developments in the AZR have to face these challenges.

Open Access This article is distributed under the terms of the Creative Commons Attribution 4.0 International License (http:// creativecommons.org/licenses/by/4.0/), which permits unrestricted use, distribution, and reproduction in any medium, provided you give appropriate credit to the original author(s) and the source, provide a link to the Creative Commons license, and indicate if changes were made. 


\section{Appendix A}

\subsection{Development of hours worked and its components}

Table A.1 Development of hours worked and its components in Germany from 1991 to 2014

\begin{tabular}{|c|c|c|c|c|c|c|c|c|c|c|c|}
\hline & & & & & & & & & & \\
\hline & & 1991 & 1992 & 1993 & 1994 & 1995 & 1996 & 1997 & 1998 & 1999 & 2000 \\
\hline \multicolumn{12}{|l|}{ A. Employees } \\
\hline \multicolumn{12}{|l|}{ Persons } \\
\hline Employees & 1,000 & 35,227 & 34,675 & 34,120 & 34,052 & 34,161 & 34,115 & 34,036 & 34,447 & 35,046 & 35,922 \\
\hline Full-time & $"$ & 28,911 & 27,970 & 27,098 & 26,696 & 26,355 & 25,860 & 25,240 & 25,055 & 25,119 & 25,309 \\
\hline Part-time & " & 6,316 & 6,705 & 7,022 & 7,356 & 7,806 & 8,255 & 8,796 & 9,392 & 9,927 & 10,613 \\
\hline Part-time rate & $\%$ & 17.9 & 19.3 & 20.6 & 21.6 & 22.9 & 24.2 & 25.8 & 27.3 & 28.3 & 29.5 \\
\hline Persons with secondary jobs & 1,000 & 884 & 904 & 949 & 969 & 1,187 & 1,230 & 1,258 & 1,293 & 1,322 & 1,269 \\
\hline \multicolumn{12}{|l|}{ Potential working days } \\
\hline Calendar days & days & 365 & 366 & 365 & 365 & 365 & 366 & 365 & 365 & 365 & 366 \\
\hline Saturdays/Sundays & $"$ & 104 & 104 & 104 & 105 & 105 & 104 & 104 & 104 & 104 & 106 \\
\hline Public holidays & $"$ & 12.9 & 10.4 & 8.9 & 9.2 & 10.3 & 12.0 & 11.7 & 9.4 & 7.9 & 10.3 \\
\hline Potential working days & days & 248.1 & 251.6 & 252.1 & 250.8 & 249.7 & 250.0 & 249.3 & 251.6 & 253.1 & 249.7 \\
\hline \multicolumn{12}{|c|}{ Collectively agreed/customary working hours } \\
\hline Weekly working hours Full-time & hours & 39.09 & 38.71 & 38.49 & 38.34 & 38.24 & 38.03 & 38.03 & 37.99 & 37.99 & 37.98 \\
\hline Part-time & $"$ & 16.33 & 15.92 & 16.04 & 15.98 & 15.50 & 15.20 & 14.90 & 14.75 & 14.53 & 14.36 \\
\hline Weekly working hours (all employees) & hours & 35.01 & 34.31 & 33.87 & 33.51 & 33.04 & 32.51 & 32.05 & 31.65 & 31.34 & 31.00 \\
\hline Coll. Agreed/customary working hours & hours & $1,737.2$ & $1,726.5$ & $1,707.6$ & $1,680.7$ & $1,650.1$ & $1,625.7$ & $1,597.8$ & $1,593.0$ & $1,586.5$ & $1,548.1$ \\
\hline \multicolumn{12}{|l|}{ Holidays } \\
\hline Holidays and other release times & days & 30.3 & 30.6 & 31.1 & 31.1 & 31.1 & 31.1 & 31.1 & 31.1 & 31.1 & 31.0 \\
\hline of these coll. agreed regular holidays & $"$ & 28.2 & 28.5 & 29.0 & 29.0 & 29.2 & 29.2 & 29.2 & 29.2 & 29.2 & 29.2 \\
\hline \multicolumn{12}{|l|}{ Sick leave } \\
\hline Sick leave by persons & $\%$ & 5.15 & 5.07 & 4.88 & 4.97 & 5.22 & 4.82 & 4.31 & 4.26 & 4.30 & 4.31 \\
\hline Sick leave in working days & days & 12.8 & 12.8 & $\begin{array}{l}12.3 \\
83.4\end{array}$ & 12.5 & 13.0 & 12.0 & 10.8 & 10.7 & 10.9 & $\begin{array}{l}10.8 \\
66.8\end{array}$ \\
\hline \multicolumn{12}{|l|}{ Effective working days } \\
\hline Working days without holidays and sick leave & Tage & 205.0 & 208.3 & 208.7 & 207.2 & 205.5 & 206.9 & 207.5 & 209.8 & 211.1 & 207.9 \\
\hline \multicolumn{12}{|l|}{ Overtime } \\
\hline Paid overtime per employee & hours & 46.7 & 48.4 & 37.5 & 38.4 & 45.5 & 39.9 & 32.0 & 33.5 & 32.0 & 30.8 \\
\hline Paid volume of overtime & Mio. hours & 1,644 & 1,680 & 1,278 & 1,309 & 1,553 & 1,363 & 1,090 & 1,153 & 1,123 & 1,106 \\
\hline Unpaid overtime per employee & hours & 26.0 & 23.1 & 26.3 & 28.8 & 28.7 & 30.0 & 33.6 & 34.1 & 30.9 & 28.4 \\
\hline Unpaid volume of overtime & Mio. hours & 916 & 800 & 897 & 982 & 981 & 1,025 & 1,143 & 1,175 & 1,083 & 1,022 \\
\hline \multicolumn{12}{|l|}{ Effect of working time accounts } \\
\hline Changes in balance & hours & +0.2 & 0.9 & 0.0 & 0.6 & -0.2 & 0.4 & 0.6 & 0.0 & 1.3 & -1.4 \\
\hline \multicolumn{12}{|l|}{ Short-time work } \\
\hline $\begin{array}{l}\text { Short-time workers } \\
\text { Hours lost per short-time worker }\end{array}$ & $\begin{array}{c}1,000 \\
\%\end{array}$ & $\begin{array}{l}1,761 \\
58.5\end{array}$ & $\begin{aligned} 653 \\
462\end{aligned}$ & $\begin{aligned} 948 \\
340\end{aligned}$ & 372 & $\begin{aligned} 199 \\
456\end{aligned}$ & 277 & 183 & $\begin{aligned} 115 \\
69\end{aligned}$ & $\begin{aligned} 119 \\
428\end{aligned}$ & 86 \\
\hline $\begin{array}{l}\text { Hours lost per short-time worker } \\
\text { Hours lost per short-time worker }\end{array}$ & $\begin{array}{c}\% \\
\text { hours }\end{array}$ & $\begin{array}{r}58.5 \\
889.0\end{array}$ & $\begin{array}{r}46.2 \\
7021\end{array}$ & 34.0 & $\begin{array}{r}37.9 \\
561.1\end{array}$ & 45.6 & $\begin{array}{r}42.2 \\
614.2\end{array}$ & $\begin{array}{r}46.2 \\
6728\end{array}$ & $\begin{array}{r}46.9 \\
6879\end{array}$ & 42.8 & $\begin{array}{r}55.0 \\
795.1\end{array}$ \\
\hline $\begin{array}{l}\text { Hours lost per short-time worker } \\
\text { Volume of hours lost }\end{array}$ & $\begin{array}{c}\text { hours } \\
\text { Mio. hours }\end{array}$ & $\begin{array}{c}889.0 \\
1,566\end{array}$ & $\begin{array}{r}702.1 \\
458\end{array}$ & $\begin{array}{r}510.6 \\
484\end{array}$ & $\begin{array}{r}561.1 \\
209\end{array}$ & $\begin{array}{r}664.7 \\
132\end{array}$ & $\begin{array}{r}614.3 \\
170\end{array}$ & $\begin{array}{r}672.8 \\
123\end{array}$ & $\begin{array}{r}687.9 \\
79\end{array}$ & $\begin{array}{r}629.2 \\
75\end{array}$ & $\begin{array}{r}795.1 \\
68\end{array}$ \\
\hline $\begin{array}{l}\text { Volume of hours lost } \\
\text { Short-time work effect }\end{array}$ & hours & 1,000 & $\frac{458}{13.2}$ & \begin{tabular}{c|c|}
484 \\
14.2
\end{tabular} & $\frac{209}{6.1}$ & $\begin{array}{ll}132 \\
3.9\end{array}$ & 5.0 & $\frac{123}{3.6}$ & $\frac{19}{2.3}$ & $\begin{array}{c}75 \\
2.1\end{array}$ & $\frac{68}{19}$ \\
\hline \multicolumn{12}{|l|}{ Other hours worked lost } \\
\hline Bad weather effect & hours & 2.3 & 2.0 & 3.1 & 1.6 & 2.1 & 2.5 & 1.5 & 1.1 & 1.6 & 1.2 \\
\hline Labour dispute effect & " & 0.03 & 0.31 & 0.13 & 0.05 & 0.05 & 0.02 & 0.01 & 0.00 & 0.02 & 0.00 \\
\hline
\end{tabular}


Table A.1 (continued) Development of hours worked and its components in Germany from 1991 to 2014

\begin{tabular}{|c|c|c|c|c|c|c|c|c|c|c|c|}
\hline & & 1991 & 1992 & 1993 & 1994 & 1995 & 1996 & 1997 & 1998 & 1999 & 2000 \\
\hline \multicolumn{12}{|l|}{ A. Employees } \\
\hline \multicolumn{12}{|l|}{ Adjustment for differences in the calendar } \\
\hline Effect & hours & +8.2 & 6.9 & 8.8 & 3.0 & 4.5 & +2.9 & 6.1 & -3.4 & 9.2 & +4.4 \\
\hline \multicolumn{12}{|l|}{ Effective working time } \\
\hline Hours worked full- and part-time & hours & $1,469.8$ & $1,479.1$ & $1,451.4$ & $1,444.5$ & $1,430.7$ & $1,411.1$ & $1,396.9$ & $1,389.2$ & $1,372.1$ & $1,348.1$ \\
\hline Changes against previous year & $\%$ & & +0.6 & -1.9 & -0.5 & -1.0 & -1.4 & -1.0 & -0.6 & -1.2 & -1.7 \\
\hline Volume of work & Mio. hours & 51,777 & 51,288 & 49,522 & 49,188 & 48,874 & 48,140 & 47,545 & 47,854 & 48,087 & 48,426 \\
\hline Changes against previous year & $\%$ & & -0.9 & $-\quad 3.4$ & $-\quad 0.7$ & -0.6 & -1.5 & -1.2 & $\begin{array}{r}+\quad 0.6 \\
\end{array}$ & $+\quad 0.5$ & $+\quad 0.7$ \\
\hline Hours worked full-time & hours & $1,642.8$ & $1,672.6$ & $1,652.3$ & $1,657.5$ & $1,660.4$ & $1,655.7$ & $1,663.2$ & $1,674.0$ & $1,669.3$ & $1,657.9$ \\
\hline Changes against previous year & $\%$ & & +1.8 & -1.2 & +0.3 & +0.2 & -0.3 & +0.5 & +0.6 & -0.3 & -0.7 \\
\hline Volume of work & Mio. hours & 47,494 & 46,783 & 44,773 & 44,249 & 43,759 & 42,818 & 41,979 & 41,942 & 41,930 & 41,959 \\
\hline Changes against previous year & $\%$ & & $-\quad 1.5$ & -4.3 & $-\quad 1.2$ & $-\quad 1.1$ & $-\quad 2.2$ & -2.0 & $-\quad 0.1$ & $\begin{array}{l}-\quad 0.0 \\
\end{array}$ & $\begin{array}{r}+ \\
+\quad 0.1 \\
\end{array}$ \\
\hline Hours worked part-time & hours & 677.8 & 671.9 & 676.4 & 671.2 & 655.3 & 644.8 & 632.9 & 629.3 & 620.1 & 609.4 \\
\hline Changes against previous year & $\%$ & & $-\quad 0.9$ & $+\quad 0.7$ & $-\quad 0.8$ & $-\quad 2.4$ & -1.6 & $-\quad 1.9$ & $-\quad 0.6$ & $-\quad 1.5$ & $-\quad 1.7$ \\
\hline Volume of work & Mio. hours & 4,281 & 4,505 & 4,750 & 4,938 & 5,115 & 5,323 & 5,567 & 5,910 & 6,156 & 6,468 \\
\hline Changes against previous year & $\%$ & & $\begin{array}{r}+ \\
+\quad 5.2 \\
\end{array}$ & $\begin{array}{r}+ \\
+\quad 5.4 \\
\end{array}$ & $\begin{array}{r}+4.0 \\
+\end{array}$ & $\begin{array}{r}+3.6 \\
\end{array}$ & $\begin{array}{r}+ \\
+\quad 4.1 \\
\end{array}$ & $\begin{array}{r}+ \\
+\quad 4.6 \\
\end{array}$ & $\begin{array}{r}+\quad 6.2 \\
\end{array}$ & $\begin{array}{r}+\quad 4.2 \\
\end{array}$ & $\begin{array}{r}+ \\
+\quad 5.1 \\
\end{array}$ \\
\hline Hours worked in secondary jobs & hours & 355.0 & 352.6 & 339.7 & 325.3 & 317.7 & 330.0 & 318.7 & 316.5 & 326.3 & 322.8 \\
\hline Volume of work & Mio. hours & 314 & 319 & 322 & 315 & 377 & 406 & 401 & 409 & 431 & 410 \\
\hline Effect of secondary jobs & hours & 8.9 & 9.2 & 9.4 & 9.3 & 11.0 & \begin{tabular}{r|}
11.9 \\
\end{tabular} & 11.8 & 11.9 & 12.3 & 11.4 \\
\hline Hours worked including second & hours & $1,478.7$ & $1,488.3$ & $1,460.9$ & $1,453.7$ & $1,441.8$ & $1,423.0$ & $1,408.7$ & $1,401.0$ & $1,384.4$ & $1,359.5$ \\
\hline Changes against previou & $\%$ & & +0.6 & -1.8 & -0.5 & -0.8 & -1.3 & -1.0 & -0.5 & -1.2 & -1.8 \\
\hline Volume of work & Mio. hours & 52,089 & 51,606 & 49,844 & 49,502 & 49,252 & 48,546 & 47,947 & 48,262 & 48,517 & 48,837 \\
\hline Changes against previous year & $\%$ & & -0.9 & $-\quad 3.4$ & $-\quad 0.7$ & $-\quad 0.5$ & -1.4 & -1.2 & $\begin{array}{r}2 \\
+\quad 0.7 \\
\end{array}$ & $\begin{array}{r}+ \\
+\quad 0.5 \\
\end{array}$ & $\begin{array}{l}0.7 \\
+\quad 0.7 \\
\end{array}$ \\
\hline For information: Effect of working days & $\%$ & & +1.4 & +0.2 & -0.5 & -0.4 & +0.1 & -0.3 & +0.9 & 0.6 & -1.3 \\
\hline Daily hours worked & & & - 0.7 & 2.0 & +0.0 & - 0.4 & & & & & \\
\hline \multicolumn{12}{|l|}{ B. Self-employed and family workers } \\
\hline Persons & 1,000 & 3,563 & 3,608 & 3,666 & 3,746 & 3,797 & 3,854 & 3,911 & 3,960 & 3,985 & 3,995 \\
\hline Hours worked & hours & $2,293.4$ & $2,299.2$ & $2,292.8$ & $2,296.6$ & $2,303.8$ & $2,284.9$ & $2,290.9$ & $2,298.6$ & $2,308.3$ & $2,283.6$ \\
\hline Changes against previous year & $\%$ & & $+\quad 0.3$ & $-\quad 0.3$ & $+\quad 0.2$ & $+\quad 0.3$ & -0.8 & $+\quad 0.3$ & $+\quad 0.3$ & $+\quad 0.4$ & -1.1 \\
\hline Volume of work & Mio. hours & 8,171 & 8,295 & 8,405 & 8,603 & 8,748 & 8,806 & 8,960 & 9,103 & 9,199 & 9,123 \\
\hline Changes against previous year & $\%$ & & $+\quad 1.5$ & $+\quad 1.3$ & $\begin{array}{r}+ \\
+\quad 2.4 \\
\end{array}$ & $+\quad 1.7$ & $+\quad 0.7$ & $\begin{array}{r}+1.7 \\
\end{array}$ & $+\quad 1.6$ & $+\quad 1.1$ & $-\quad 0.8$ \\
\hline \multicolumn{12}{|l|}{ C. Persons in employment } \\
\hline Persons & 1,000 & 38,790 & 38,283 & 37,786 & 37,798 & 37,958 & 37,969 & 37,947 & 38,407 & 39,031 & 39,917 \\
\hline Hours worked & hours & $1,553.5$ & $1,564.7$ & $1,541.6$ & $1,537.3$ & $1,528.0$ & $1,510.5$ & $1,499.6$ & $1,493.6$ & $1,478.7$ & $1,452.0$ \\
\hline Changes against previous year & $\%$ & & +0.7 & -1.5 & -0.3 & -0.6 & -1.1 & -0.7 & -0.4 & -1.0 & -1.8 \\
\hline Volume of work & Mio. hours & 60,261 & 59,902 & 58,250 & 58,105 & 57,999 & 57,352 & 56,907 & 57,364 & 57,716 & 57,960 \\
\hline Changes against previous year & $\%$ & & -0.6 & -2.8 & -0.2 & -0.2 & -1.1 & -0.8 & +0.8 & +0.6 & +0.4 \\
\hline
\end{tabular}


Table A.1 (continued) Development of hours worked and its components in Germany from 1991 to 2014

\begin{tabular}{|c|c|c|c|c|c|c|c|c|c|c|c|}
\hline & & 2001 & 2002 & 2003 & 2004 & 2005 & 2006 & 2007 & 2008 & 2009 & 2010 \\
\hline \multicolumn{12}{|l|}{ A. Employees } \\
\hline \multicolumn{12}{|l|}{ Persons } \\
\hline Employees & 1,000 & 35,797 & 35,570 & 35,078 & 35,079 & 34,916 & 35,152 & 35,798 & 36,353 & 36,407 & 36,533 \\
\hline Full-time & " & 25,062 & 24,639 & 23,966 & 23,394 & 22,923 & 22,866 & 23,230 & 23,271 & 22,902 & 22,825 \\
\hline \begin{tabular}{|l} 
Part-time \\
\end{tabular} & $"$ & 10,735 & 10,931 & 11,112 & 11,685 & 11,993 & 12,286 & 12,568 & 13,082 & 13,505 & 13,708 \\
\hline \begin{tabular}{|l|} 
Part-time rate \\
\end{tabular} & $\%$ & 30.0 & 30.7 & 31.7 & 33.3 & 34.3 & 34.9 & 35.1 & 36.0 & 37.1 & 37.5 \\
\hline Persons with secondary jobs & 1,000 & 1,254 & 1,228 & 1,290 & 1,635 & 1,781 & 1,888 & 2,037 & 2,201 & 2,277 & 2,333 \\
\hline \multicolumn{12}{|l|}{ Potential working days } \\
\hline Calendar days & days & 365 & 365 & 365 & 366 & 365 & 365 & 365 & 366 & 365 & 365 \\
\hline Saturdays/Sundays & $"$ & 104 & 104 & 104 & 104 & 105 & 105 & 104 & 104 & 104 & 104 \\
\hline Public holidays & $"$ & 12.0 & 12.0 & 11.7 & 8.0 & 8.3 & 10.4 & 12.0 & 10.4 & 9.4 & 8.0 \\
\hline Potential working days & days & 249.0 & 249.0 & 249.3 & 254.0 & 251.7 & 249.6 & 249.0 & 251.6 & 251.6 & 253.0 \\
\hline \multicolumn{12}{|c|}{ Collectively agreed/customary working hours } \\
\hline Weekly working hours Full-time & hours & 37.96 & 37.96 & 37.97 & 37.93 & 37.97 & 38.05 & 38.04 & 38.02 & 37.78 & 37.93 \\
\hline Part-time & & 14.27 & 14.31 & 14.33 & 14.17 & 14.69 & 14.93 & 15.15 & 15.44 & 15.25 & 15.31 \\
\hline Weekly working hours (all employees) & hours & 30.86 & 30.70 & 30.48 & 30.02 & 29.97 & 29.97 & 30.00 & 29.89 & 29.42 & 29.44 \\
\hline Coll. Agreed/customary working hours & hours & $1,536.9$ & $1,528.9$ & $1,519.5$ & $1,524.8$ & $1,508.8$ & $1,496.4$ & $1,494.2$ & $1,504.2$ & $1,480.5$ & $1,490.0$ \\
\hline Holidays & & & & & & & & & & & \\
\hline Holidays and other release times & days & 31.0 & 31.0 & 30.9 & 30.9 & 30.8 & 30.8 & 30.7 & 31.0 & 30.7 & 30.7 \\
\hline \begin{tabular}{|l} 
of these coll. agreed regular holidays \\
\end{tabular} & & 29.3 & 29.3 & 29.3 & 29.3 & 29.3 & 29.3 & 29.3 & 29.3 & 29.3 & 29.3 \\
\hline Sick leave & & & & & & & & & & & \\
\hline Sick leave by persons & $\%$ & 4.25 & 4.08 & 3.68 & 3.41 & 3.64 & 3.29 & 3.26 & 3.41 & 3.50 & 3.71 \\
\hline Sick leave in working days & days & 10.6 & 10.2 & 9.2 & 8.7 & 9.2 & 8.2 & 8.1 & 8.6 & 8.8 & 9.4 \\
\hline Sick leave in hours worked & hours & 65.3 & 62.4 & 55.9 & 52.0 & 55.0 & 49.3 & 48.7 & 51.4 & 51.8 & 55.2 \\
\hline Effective working days & & & & & & & & & & & \\
\hline Working days without holidays and sick leave & Tage & 207.4 & 207.9 & 209.2 & 214.5 & 211.7 & 210.7 & 210.2 & 212.1 & 212.1 & 213.0 \\
\hline Overtime & & & & & & & & & & & \\
\hline Paid overtime per employee & hours & 29.6 & 24.5 & 23.6 & 23.2 & 22.1 & 23.8 & 24.5 & 23.1 & 18.5 & 20.3 \\
\hline Paid volume of overtime & Mio. hours & 1,061 & 873 & 829 & 812 & 773 & 838 & 876 & 841 & 673 & 742 \\
\hline Unpaid overtime per employee & hours & 27.3 & 28.5 & 27.1 & 29.0 & 29.7 & 35.0 & 35.1 & 33.5 & 30.7 & 31.6 \\
\hline Unpaid volume of overtime & Mio. hours & 977 & 1,014 & 951 & 1,018 & 1,038 & 1,230 & 1,255 & 1,218 & 1,119 & 1,153 \\
\hline Effect of working time accounts & & & & & & & & & & & \\
\hline Changes in balance & hours & +1.1 & +2.5 & +0.5 & -3.5 & -6.5 & +5.4 & 4.7 & +1.9 & -9.5 & 1.0 \\
\hline Short-time work & & & & & & & & & & & \\
\hline Short-time workers & 1,000 & 123 & 207 & 195 & 150 & 125 & 67 & 68 & 101 & 1,144 & 503 \\
\hline Hours lost per short-time worker & $\%$ & 48.9 & 43.2 & 44.8 & 50.9 & 51.1 & 53.1 & 55.9 & 46.6 & 28.0 & 34.2 \\
\hline Hours lost per short-time worker & hours & 703.9 & 621.6 & 646.3 & 749.1 & 743.4 & 768.3 & 806.4 & 672.2 & 398.0 & 488.8 \\
\hline Volume of hours lost & Mio. hours & 87 & 129 & 126 & 113 & 93 & 51 & 55 & 68 & 455 & 246 \\
\hline Short-time work effect & hours & 2.4 & 3.6 & 3.6 & 3.2 & 2.7 & 1.5 & 1.5 & 1.9 & 12.5 & 6.7 \\
\hline Other hours worked lost & & & & & & & & & & & \\
\hline Bad weath & hours & 1.2 & 1.2 & 1.5 & 1.0 & 1.3 & 1.2 & 0.0 & 0.0 & 0.0 & 0.0 \\
\hline Labour dispute effect & & 0.00 & 0.06 & 0.03 & 0.01 & 0.00 & 0.07 & 0.06 & 0.03 & 0.01 & 0.00 \\
\hline Adjustment for differences in the calenda & & & & & & & & & & & \\
\hline Effect & hours & 6.8 & +6.7 & +5.9 & -12.4 & -3.5 & +4.3 & 6.4 & -3.1 & -3.4 & -8.1 \\
\hline Effective working time & & & & & & & & & & & \\
\hline I- and part-time & hours & $1,341.4$ & $1,333.7$ & $1,327.4$ & $1,319.6$ & $1,307.3$ & $1,328.5$ & $1,330.2$ & $1,321.4$ & $1,271.9$ & $1,292.2$ \\
\hline Changes against previous year & $\%$ & -0.5 & -0.6 & -0.5 & -0.6 & -0.9 & +1.6 & +0.1 & -0.7 & - 3.7 & +1.6 \\
\hline of work & Mio. hours & 48,018 & 47,440 & 46,563 & 46,290 & 45,646 & 46,699 & 47,618 & 48,037 & 46,306 & 47,208 \\
\hline Changes against previous year & $\%$ & -0.8 & $\begin{array}{l}-\quad 1.2 \\
\end{array}$ & -1.8 & -0.6 & $\begin{array}{l}-\quad 1.4 \\
\end{array}$ & $+\quad 2.3$ & $+\quad 2.0$ & $+\quad 0.9$ & -3.6 & $\begin{array}{r}+\quad 1.9 \\
\end{array}$ \\
\hline \begin{tabular}{|l|} 
Hours worked full-time \\
\end{tabular} & hours & $1,655.4$ & $1,655.1$ & $1,658.8$ & $1,673.3$ & $1,662.6$ & $1,692.2$ & $1,693.1$ & $1,686.8$ & $1,635.8$ & $1,663.5$ \\
\hline previous year & $\%$ & -0.1 & -0.0 & +0.2 & +0.9 & -0.6 & +1.8 & +0.1 & -0.4 & -3.0 & +1.7 \\
\hline Volume of work & Mio. hours & 41,489 & 40,780 & 39,756 & 39,146 & 38,112 & 38,694 & 39,331 & 39,255 & 37,463 & 37,971 \\
\hline ainst previous year & $\%$ & -1.1 & -1.7 & -2.5 & -1.5 & -2.6 & +1.5 & +1.6 & -0.2 & -4.6 & +1.4 \\
\hline Hours worked part-time & hours & 608.3 & 609.3 & 612.7 & 611.5 & 628.2 & 651.7 & 659.3 & 671.5 & 654.9 & 673.8 \\
\hline evious year & $\%$ & -0.2 & +0.2 & +0.5 & -0.2 & +2.7 & +3.7 & +1.2 & +1.8 & -2.5 & +2.9 \\
\hline Volume of & Mio. hours & 6,530 & 6,660 & 6,808 & 7,146 & 7,534 & 8,006 & 8,286 & 8,784 & 8,845 & 9,236 \\
\hline gainst previous year & $\%$ & $+\quad 1.0$ & $+\quad 2.0$ & $\begin{array}{r}+\quad 2.2 \\
\end{array}$ & $\begin{array}{r}+\quad 5.0 \\
\end{array}$ & $\begin{array}{r}+\quad 5.4 \\
\end{array}$ & $+\quad 6.3$ & $+\quad 3.5$ & +6.0 & $\begin{array}{r}+\quad 0.7 \\
\end{array}$ & $\begin{array}{r}+\quad 4.4 \\
\end{array}$ \\
\hline Hours v & hours & 320.9 & 320.4 & 317.6 & 321.6 & 319.7 & 282.5 & 285.5 & 299.5 & 276.2 & 273.6 \\
\hline Volume & Mio. hours & 402 & 393 & 410 & 526 & 569 & 533 & 582 & 659 & 629 & 638 \\
\hline Effect of secondary jobs & hours & & 11.1 & 11.7 & 15.0 & 16.3 & 15.2 & 16.2 & 18.1 & 17.3 & 17.5 \\
\hline Hours worked including secondary jobs & hours & $1,352.7$ & $1,344.8$ & $1,339.1$ & $1,334.6$ & $1,323.6$ & $1,343.7$ & $1,346.4$ & $1,339.6$ & $1,289.2$ & $1,309.7$ \\
\hline Change & $\%$ & -0.5 & -0.6 & - 0.4 & -0.3 & -0.8 & +1.5 & +0.2 & -0.5 & -3.8 & +1.6 \\
\hline Volume of work & Mio. hours & 48,421 & 47,834 & 46,973 & 46,817 & 46,215 & 47,234 & 48,199 & 48,698 & 46,937 & 47,846 \\
\hline Changes against previous year & $\%$ & -0.9 & -1.2 & -1.8 & -0.3 & -1.3 & $+\quad 2.2$ & $+\quad 2.0$ & $+\quad 1.0$ & -3.6 & $+\quad 1.9$ \\
\hline For information: Effe & $\%$ & -0.3 & +0.0 & +0.1 & +1.9 & -0.9 & -0.8 & 0.3 & +1.0 & -0.0 & +0.6 \\
\hline \begin{tabular}{|r} 
Daily ho \\
\end{tabular} & & -0.2 & -0.6 & -0.5 & $-\quad 2.2$ & $+\quad 0.1$ & $+\quad 2.3$ & 0.5 & -1.5 & 3.7 & $\begin{array}{r}+\quad 1.0 \\
\end{array}$ \\
\hline B. Self-employed and $f$ & & & & & & & & & & & \\
\hline \begin{tabular}{|l|} 
Persons \\
\end{tabular} & 1,000 & 4,012 & 4,060 & 4,122 & 4,258 & 4,410 & 4,483 & 4,527 & 4,503 & 4,485 & 4,487 \\
\hline Hours worked & hours & $2,238.1$ & $2,185.1$ & $2,153.6$ & $2,143.9$ & $2,105.4$ & $2,059.8$ & $2,040.7$ & $2,054.7$ & $2,050.5$ & $2,043.0$ \\
\hline Changes against previous year & $\%$ & -2.0 & -2.4 & -1.4 & -0.5 & -1.8 & -2.2 & -0.9 & $+\quad 0.7$ & -0.2 & -0.4 \\
\hline Volume of work & Mio. hours & 8,979 & 8,871 & 8,877 & 9,129 & 9,285 & 9,234 & 9,238 & 9,252 & 9,196 & 9,167 \\
\hline Changes against previous year & $\%$ & $\begin{array}{l}-\quad 1.6 \\
-150\end{array}$ & -1.2 & $\begin{array}{r}+\quad 0.1 \\
+\quad 1\end{array}$ & $\begin{array}{r}+\quad 2.8 \\
+\end{array}$ & $\begin{array}{r}+\quad 1.7 \\
+\end{array}$ & $\begin{array}{r}-\quad 0.5 \\
-\end{array}$ & $\begin{array}{r}+0.0 \\
+\quad 0\end{array}$ & $\begin{array}{r}+\quad 0.2 \\
+\quad 3\end{array}$ & -0.6 & $\begin{array}{r}-0.3 \\
-\end{array}$ \\
\hline \begin{tabular}{|l|} 
C. Persons in employment \\
\end{tabular} & & & & & & & & & & & \\
\hline Persons & 1,000 & 39,809 & 39,630 & 39,200 & 39,337 & 39,326 & 39,635 & 40,325 & 40,856 & 40,892 & 41,020 \\
\hline Hours work & hours & $1,441.9$ & $1,430.9$ & $1,424.8$ & $1,422.2$ & $1,411.3$ & $1,424.7$ & $1,424.4$ & $1,418.4$ & $1,372.7$ & $1,389.9$ \\
\hline Changes against pr & $\%$ & -0.7 & -0.8 & -0.4 & -0.2 & -0.8 & +0.9 & -0.0 & -0.4 & -3.2 & +1.3 \\
\hline Volume of work & Mio. hours & 57,401 & 56,705 & 55,850 & 55,946 & 55,500 & 56,467 & 57,437 & 57,950 & 56,133 & 57,013 \\
\hline Changes against previous year & $\%$ & -1.0 & -1.2 & $\begin{array}{r}-\quad 1.5 \\
\end{array}$ & +0.2 & -0.8 & +1.7 & +1.7 & +0.9 & $-\quad 3.1$ & +1.6 \\
\hline
\end{tabular}


Table A.1 (continued) Development of hours worked and its components in Germany from 1991 to 2014

\begin{tabular}{|c|c|c|c|c|c|}
\hline & \multirow[b]{2}{*}{2011} & \multirow[b]{2}{*}{2012} & \multirow[b]{2}{*}{2013} & \multirow[b]{2}{*}{2014} \\
\hline & & & & & \\
\hline A. Employees & & & & & \\
\hline Persons & & & & & \\
\hline Employees & 1,000 & 37,024 & 37,489 & 37,824 & 38,247 \\
\hline Full-time & $"$ & 22,921 & 23,211 & 23,279 & 23,468 \\
\hline Part-time & " & 14,103 & 14,278 & 14,545 & 14,779 \\
\hline Part-time rate & $\%$ & 38.1 & 38.1 & 38.5 & 38.6 \\
\hline Persons with secondary jobs & 1,000 & 2,461 & 2,563 & 2,674 & 2,771 \\
\hline Potential working days & & & & & \\
\hline Calendar days & days & 365 & 366 & 365 & 365 \\
\hline Saturdays/Sundays & " & 105 & 105 & 104 & 104 \\
\hline Public holidays & $"$ & 8.3 & 11.4 & 12.0 & 11.7 \\
\hline Potential working days & days & 251.7 & 249.6 & 249.0 & 249.3 \\
\hline Collectively agreed/customary working ho & & & & & \\
\hline Weekly working hours Full-time & hours & 37.98 & 37.91 & 38.03 & 38.07 \\
\hline Part-time & $"$ & 15.36 & 15.49 & 15.73 & 15.89 \\
\hline Weekly working hours (all employees) & hours & 29.36 & 29.38 & 29.46 & 29.50 \\
\hline Coll. Agreed/customary working hours & hours & $1,477.9$ & $1,466.7$ & $1,467.2$ & $1,470.4$ \\
\hline Annual paid holidays & & & & & \\
\hline Holidays and other release times & days & 30.7 & 30.8 & 31.4 & 31.2 \\
\hline of these coll. agreed regular holidays & " & 29.3 & 29.4 & 29.7 & 29.7 \\
\hline Sick leave & & & & & \\
\hline Sick leave by persons & $\%$ & 3.84 & 3.71 & 3.83 & 3.81 \\
\hline Sick leave in working days & days & 9.7 & 9.3 & 9.5 & 9.5 \\
\hline Sick leave in hours worked & hours & 56.8 & 54.5 & 56.3 & 56.0 \\
\hline Effective working days & & & & & \\
\hline Working days without holidays and sick leave & Tage & 211.3 & 209.5 & 208.1 & 208.6 \\
\hline Overtime & & & & & \\
\hline Paid overtime per employee & hours & 24.6 & 22.6 & 20.0 & 21.1 \\
\hline Paid volume of overtime & Mio. hours & 911 & 848 & 758 & 806 \\
\hline Unpaid overtime per employee & hours & 32.4 & 27.8 & 27.2 & 27.8 \\
\hline Unpaid volume of overtime & Mio. hours & 1,201 & 1,041 & 1,030 & 1,062 \\
\hline Effect of working time accounts & & & & & \\
\hline Changes in balance & hours & +6.1 & 0.0 & 3.0 & 1.3 \\
\hline Short-time work & & & & & \\
\hline Short-time workers & 1,000 & 148 & 111 & 124 & 93 \\
\hline Hours lost per short-time worker & $\%$ & 39.4 & 39.9 & 40.5 & 42.9 \\
\hline Hours lost per short-time worker & hours & 555.1 & 554.4 & 559.5 & 592.6 \\
\hline Volume of hours lost & Mio. hours & 82 & 62 & 69 & 55 \\
\hline Short-time work effect & hours & 2.2 & 1.6 & 1.8 & 1.4 \\
\hline Other hours worked lost & & & & & \\
\hline Bad weather effect & hours & 0.0 & 0.0 & 0.0 & 0.0 \\
\hline Strikes and lock-outs effect & $"$ & 0.01 & 0.02 & 0.03 & 0.03 \\
\hline Adjustment for differences in the calendar & & & & & \\
\hline Effect & hours & 3.3 & +3.9 & +6.1 & +5.4 \\
\hline Effective working time & & & & & \\
\hline Hours worked full- and part-time & hours & $1,298.4$ & $1,283.7$ & $1,274.6$ & $1,284.6$ \\
\hline Changes against previous year & $\%$ & +0.5 & -1.1 & -0.7 & +0.8 \\
\hline Volume of work & Mio. hours & 48,072 & 48,125 & 48,210 & 49,132 \\
\hline Changes against previous year & $\%$ & +1.8 & +0.1 & +0.2 & +1.9 \\
\hline Hours worked full-time & hours & $1,678.2$ & $1,655.7$ & $1,645.1$ & $1,657.0$ \\
\hline Changes against previous year & $\%$ & +0.9 & -1.3 & -0.6 & +0.7 \\
\hline Volume of work & Mio. hours & 38,466 & 38,432 & 38,296 & 38,886 \\
\hline Changes against previous year & $\%$ & $+\quad 1.3$ & -0.1 & & +1.5 \\
\hline Hours worked part-time & hours & 681.2 & 679.0 & 681.6 & 693.4 \\
\hline Changes against previous year & $\%$ & +1.1 & -0.3 & +0.4 & +1.7 \\
\hline Volume of work & Mio. hours & 9,607 & 9,694 & 9,914 & 10,248 \\
\hline Changes against previous year & $\%$ & +4.0 & +0.9 & +2.3 & $+\quad 3.4$ \\
\hline Hours worked in secondary jobs & hours & 255.0 & 238.2 & 233.0 & 234.4 \\
\hline Volume of work & Mio. hours & 628 & 610 & 623 & 650 \\
\hline Effect of secondary jobs & hours & 17.0 & 16.3 & 16.5 & 17.0 \\
\hline Hours worked including secondary jobs & hours & $1,315.4$ & $1,300.0$ & $1,291.1$ & $1,301.6$ \\
\hline Changes against previous year & $\%$ & +0.4 & -1.2 & -0.7 & +0.8 \\
\hline Volume of work & Mio. hours & 48,701 & 48,736 & 48,833 & 49,783 \\
\hline Changes against previous year & $\%$ & +1.8 & $+\quad 0.1$ & $+\quad 0.2$ & $+\quad 1.9$ \\
\hline For information: Effect of working days & $\%$ & -0.5 & -0.8 & & +0.1 \\
\hline Daily hours worked & & +1.0 & - 0.4 & 0.4 & +0.7 \\
\hline B. Self-employed and family workers & & & & & \\
\hline Persons & 1,000 & 4,546 & 4,544 & 4,457 & 4,405 \\
\hline Hours worked & hours & $2,026.1$ & $1,986.4$ & $1,968.7$ & $1,973.3$ \\
\hline Changes against previous year & $\%$ & -0.8 & -2.0 & -0.9 & +0.2 \\
\hline Volume of work & Mio. hours & 9,211 & 9,026 & 8,775 & 8,692 \\
\hline Changes against previous year & $\%$ & $+\quad 0.5$ & $-\quad 2.0$ & $-\quad 2.8$ & $-\quad 0.9$ \\
\hline C. Persons in employment & & & & & \\
\hline Persons & 1,000 & 41,570 & 42,033 & 42,281 & 42,652 \\
\hline Hours worked & hours & $1,393.1$ & $1,374.2$ & $1,362.5$ & $1,371.0$ \\
\hline Changes against previous year & $\%$ & +0.2 & -1.4 & -0.9 & +0.6 \\
\hline Volume of work & Mio. hours & 57,912 & 57,763 & 57,608 & 58,476 \\
\hline Changes against previous year & $\%$ & +1.6 & -0.3 & - 0.3 & $+\quad 1.5$ \\
\hline
\end{tabular}

Source: IAB working time measurement concept

Status of data delivery: March 2015 


\section{Appendix B}

\section{Special forms of employment in Germany}

\section{Employees subject to social insurance contributions}

The concept of employees subject to social insurance contributions (sozialversicherungspflichtig Beschäftigte) covers all employees incl. those undergoing vocational training who are subject to health, pension and long-term care insurance and/or to contributions pursuant to employment promotion law or for whom employers pay shares of contribution pursuant to employment promotion law. Conscripts performing compulsory military or community service are regarded as employees subject to social insurance contributions provided they were employed at the time they began their service, the employment relationship continues and they do not receive remuneration payments purely for the reason of performing that service. Public officials, self-employed persons and family workers are however not covered by the concept of employees subject to social insurance contributions.

The statistics of employees subject to social insurance contributions are secondary statistics. The statistics are based on a common procedure for reporting data for statutory health, long-term care, pension and unemployment insurance purposes. This procedure requires employers to report, in an electronic and harmonised form, data for all employees subject to social insurance contributions (complete enumeration) which are of relevance to insurance matters. The Federal Employment Agency (BA) stores the data in individual insurance records. These records form the basis for reference date-related evaluations for statistical purposes (Federal Statistical Office 2009).

\section{Marginal employment}

There are two basic types of marginal employment to be distinguished: (1) Employment for which the wage is regularly not exceeding $450 €$ per month and (2) employment which - during a calendar year - is restricted to three months or 70 working days (irrespective of the earnings). The first type is usually referred to as marginal employment with low pay (geringfügig entlohnte Beschäftigung), the second one as short-term (marginal) employment (kurzfristige Beschäftigung).

For the marginal employment with low pay, the threshold of $450 €$ refers to the "regular" monthly wage. This means that the amount can in certain cases be higher than $450 €$ in individual months, but not regularly.

Marginal employment can be carried out either as the sole employment a person holds, or as a side job combined with either a further marginal job or an employment subject to full social insurance contributions (sozialversicherungspflichtige Beschäftigung). Each of the combinations are subject to a differentiated treatment in terms of social contributions and taxation.

Workers (and their employers) whose "mini-jobs" is their main job contribute to the national retirement pension insurance in Germany. The employee pays $3.7 \%$ and the employer pays $15 \%$. They do not contribute to either the national health insurance funds or for unemployment coverage. They can either be covered by the health insurance of the higher earning partner (or parents for students up to 25 years) or they can contribute on a voluntary basis (Körner and Puch 2012).

\section{Persons in work opportunities (One-Euro-Jobs)}

One-Euro-Jobs (Arbeitsgelegenheiten in der Mehraufwandsvariante) are work opportunities providing additional jobs in the sense that they would not be undertaken without the subsidy and are of public interest for welfare recipients who are especially hard-to-place in employment. While participating in One-Euro-Jobs, welfare recipients continue to receive welfare benefits plus $1-2 €$ per hour worked. One-Euro-Jobs aim to raise the employability of the longterm unemployed and increase their chances of finding regular employment. Welfare recipients' willingness to work is also tested under the programme. Furthermore, One-Euro-Jobs aim to socially integrate welfare recipients (Dengler 2013).

\section{References}

Anger, S.: Overtime work in Germany. The investment character of unpaid hours. Shaker, Aachen (2006)

Bach, H.-U.: Arbeitsvolumen steigt wieder dank mehr Beschäftigung. IAB-Kurzbericht, vol. 3. Institut für Arbeitsmarkt- und Berufsforschung, Nürnberg (2001)

Bach, H.-U., Koch, S.: Arbeitszeit und Arbeitsvolumen. In: IABKompendium Arbeitsmarkt- und Berufsforschung, Beiträge zur Arbeitsmarkt- und Berufsforschung 250, pp. 57-70. (2002)

Bertat, T., Dundler, A., Grimm, C., Kiewitt, J., Schomaker, C., Schridde, H., Zemann, C.: Neue Erhebungsinhalte "Arbeitszeit"; "ausgeübte Tätigkeit" sowie "Schul- und Berufsabschluss" in der Beschäftigungsstatistik. Methodenbericht der Statistik der BA, Bundesagentur für Arbeit (2013). http:// statistik.arbeitsagentur.de/Statischer-Content/Grundlagen/ Methodenberichte/Beschaeftigungsstatistik/GenerischePublikationen/Methodenbericht-Neue-ErbebungsinhalteArbeitszeita-ausgeuebte-Taetigkeit-sowie-Schul-undBerufsabschluss-in-der-Beschaeftigungsstatistik.pdf. Accessed 29 April 2015

Bick, M., Decker, J.: Neuberechnung des Index der Tarifverdienste verbessert Kohärenz der Verdienststatistiken. Wirtsch Stat 10, 745-752 (2013)

Bogedan, C., Brehmer, W., Herzog-Stein, A.: Betriebliche Beschäftigungssicherung in der Krise. Eine Kurzauswertung der WSIBetriebsrätebefragung 2009 (2009). http://www.boeckler.de/pdf/ wsi_br_befragung_2009_krise_kurzauswertung.pdf. Accessed 29 April 2015 
Borjas, G.J.: The relationship between wages and weekly hours of work: the role of division bias. J Hum Resour 15, 409-423 (1980)

Brenke, K.: Erwerbstätige mit Nebentätigkeiten in Deutschland und Europa. DIW Wochenber 76(35), 598-607 (2009)

Brenke, K.: Allein tätige Selbständige: starkes Beschäftigungswachstum; oft nur geringe Einkommen. DIW Wochenber 80(7), 3-16 (2013)

Bundesmann-Jansen, J., Groß, H., Munz, E.: Arbeitszeit '99. Ergebnisse einer repräsentativen Beschäftigtenbefragung zu traditionellen und neuen Arbeitszeitformen in der Bundesrepublik Deutschland. Ministerium für Arbeit, Soziales und Stadtentwicklung, Kultur und Sport des Landes Nordrhein-Westfalen, Düsseldorf (2000)

Burda, M.C., Hunt, J.: What explains the German labor market miracle in the great recession? Brookings Pap Econ Activity 2011, 273-335 (2011)

Cabrita, J.: Developments in collectively agreed working time 2013 (2014). http://eurofound.europa.eu/observatories/eurwork/ comparative-information/developments-in-collectively-agreedworking-time-2013. Accessed 29 April 2015

Caliendo, M., Künn, S., Wießner, F.: Ich-AG und Überbrückungsgeld - Erfolgsgeschichte mit zu frühem Ende. IAB-Kurzbericht, vol. 3. Institut für Arbeitsmarkt- und Berufsforschung, Nürnberg (2009)

Carson, C.S., Laliberté, L.: Assessing accuracy and reliability: a note based on approaches used in national accounts and balance of payments statistics. IMF working paper 02/24 (2002)

Chari, V., Kehoe, P., McGrattan, E.R.: Business cycle accounting. Econometrica 75, 781-836 (2007)

Crimmann, A., Wießner, F., Bellmann, L.: The German work-sharing scheme: an instrument for the crisis. Conditions of work and employment series no. 25 (2010)

Dengler, K.: The effectiveness of sequences of One-Euro Jobs. Is it better to do more One-Euro-Jobs or to wait? IAB-Discussion paper no. 16 (2013)

Deutsche Bundesbank: Kalendarische Einflüsse auf das Wirtschaftsgeschehen. Bundesbank Mon Rep 64, 53-63 (2012)

Dietz, M., Stops, M., Walwei, U.: Safeguarding jobs through labor hoarding in Germany. In: Zimmermann, K.F., Wey, C. (eds.) The economy, crises, and the labor market. Can institutions serve as a protective shield for employment? pp. 125-149. Duncker \& Humblot, Berlin (2010). Applied Economics Quarterly 56, Supplement

Dundler, A., Frank, T.: Beschäftigungsstatistik - Umstellung der Erhebungsinhalte bei den Merkmalen "ausgeübte Tätigkeit" (Beruf), "Arbeitszeit" und "Ausbildung". Methodenbericht der Statistik der Bundesagentur für Arbeit (2012). http:// statistik.arbeitsagentur.de/Statischer-Content/Grundlagen/ Methodenberichte/Beschaeftigungsstatistik/GenerischePublikationen/Methodenbericht-TS-BST.pdf. Accessed 29 April 2015

Durbin, J., Koopman, S.J.: Time series analysis by state space methods, 2nd edn. Oxford statistical science series. Oxford University Press, Oxford (2012)

Ellguth, P., Kohaut, S.: Tarifbindung und betriebliche Interessenvertretung: Aktuelle Ergebnisse aus dem IAB-Betriebspanel 2013. WSI Mitt 67, 286-295 (2014)

European Commission: NACE Rev. 2 - Statistical classification of economic activites in the European Community, Luxembourg: Office for Official Publications of the European Communities, Eurostat - Methodologies and working papers 2008 (2008). http://ec.europa.eu/eurostat/documents/3859598/5902521/KSRA-07-015-EN.PDF/dd5443f5-b886-40e4-920d-9df03590ff91? version=1.0. Accessed 29 April 2015

European Commission: European system of accounts - ESA 2010, Luxembourg: Publications Office of the European Union 2013 (2013a). http://ec.europa.eu/eurostat/documents/3859598/
5925693/KS-02-13-269-EN.PDF/44cd9d01-bc64-40e5-bd40d17df0c69334. Accessed 29 April 2015

European Commission: Regulation (EU) No 549/2013 of the European Parliament and the Council of 21 May 2013 on the European system of national and regional accounts in the Community. Official Journal of the European Union 56 (2013b)

Federal Statistical Office: Statistics of employees subject to social insurance contributions - quarterly statistics of employees (2009). https://www.destatis. de/EN/Publications/QualityReports/LabourMarket/ StatisticsEmployeesSubjectTosociaInsuranceContributions. pdf?_blob=publicationFile (Created January 2009). Accessed 29 April 2015

Federal Statistical Office: Methodische Weiterentwicklung der Volkswirtschaftlichen Gesamtrechnungen - die Revision 2014 (2013). https://www.destatis.de/DE/ZahlenFakten/ GesamtwirtschaftUmwelt/VGR/Methoden/Downloads/ Revision2014_pdf.pdf?_blob=publicationFile (Created Januar 2013). Accessed 29 April 2015

Fleck, S.E.: International comparisons of hours worked: an assessment of the statistics. Mon Labor Rev 132, 3-31 (2009)

Frank, T., Grimm, C.: Revision der Beschäftigungsstatistik 2014. Methodenbericht der Statistik der Bundesagentur für Arbeit (2014). http://statistik.arbeitsagentur.de/ Statischer-Content/Grundlagen/Methodenberichte/ Beschaeftigungsstatistik/Generische-Publikationen/ Methodenbericht-Beschaeftigungsstatistik-Revision-2014.pdf. Accessed 29 April 2015

Fuchs, J., Hummel, M., Hutter, C., Klinger, S., Wanger, S., Weber, E., Weigand, R., Zika, G.: IAB-Prognose 2015: Der Arbeitsmarkt bleibt auf Erfolgskurs. IAB-Kurzbericht, vol. 7. Institut für Arbeitsmarkt- und Berufsforschung, Nürnberg (2015)

Gali, J.: Technology, employment, and the business cycle: Do technology shocks explain aggregate fluctuations? Am Econ Rev 89, 249-271 (1999)

Gartner, H., Klinger, S.: Verbesserte Institutionen für den Arbeitsmarkt in der Wirtschaftskrise. Wirtschaftsdienst 90(11), 728-734 (2010)

Hansen, G.D.: Indivisible labor and the business cycle. J Monet Econ 16, 309-327 (1985)

Heineck, G.: The determinants of secondary jobholding in Germany and the UK. Z Arbeitsmarktforsch 42, 107-120 (2009)

Herzog-Stein, A., Zapf, I.: Navigating the Great Recession: the impact of working-time accounts in Germany. Ind Labor Relat Rev 67, 891-925 (2014)

Hodrick, R.J., Prescott, E.C.: Postwar US business cycles: an empirical investigation. J Money Credit Bank 29, 1-16 (1997)

ILO: Resolution concerning the measurement of working time adopted by the Eighteenth International Conference of Labor Statisticians (November-December 2008) (2008). http://www. ilo.org/wcmsp5/groups/public/---dgreports/---stat/documents/ presentation/wcms_161395.pdf. Accessed 29 April 2015

Knieps, F., Pfaff, H. (eds.): Gesundheit in Regionen: Zahlen, Daten, Fakten - mit Gastbeiträgen aus Wissenschaft, Politik und Praxis. BKK Gesundheitsreport. Medizinisch Wissenschaftliche Verlagsgesellschaft, Berlin (2014)

Koch, S.: Arbeitszeitkonten stabilisieren die Beschäftigung. IAB Kurzbericht, vol. 4. Institut für Arbeitsmarkt- und Berufsforschung, Nürnberg (2001)

Kohler, H., Reyher, L.: Arbeitszeit und Arbeitsvolumen in der Bundesrepublik Deutschland 1960-1986. Datenlage - Struktur - Entwicklung. Beiträge zur Arbeitsmarkt- und Berufsforschung, vol. 123. Institut für Arbeitsmarkt- und Berufsforschung, Nürnberg (1988)

Körner, T., Puch, K.: Measuring marginal employment in surveys and registers. Statistics and Science 20, Statistisches Bundesamt (2012). 
https://www.destatis.de/DE/Publikationen/StatistikWissenschaft/ Band20_MeasuringMarginalEmployment1030820129004.pdf?_ blob=publicationFile. Accessed 29 April 2015

Krieg, S., van den Brakel, J.: Estimation of the monthly unemployment rate for six domains through structural time series modelling with cointegrated trends. Comput Stat Data Anal 56, 2918-2933 (2012)

Küsgens, I., Vetter, C., Yoldas, B.: Krankheitsbedingte Fehlzeiten in der deutschen Wirtschaft. In: Badura, B., Litsch, M., Vetter, C. (eds.) Fehlzeiten-Report 2001: Gesundheitsmanagement im öffentlichen Sektor. Zahlen, Daten, Analysen aus allen Branchen der Wirtschaft, pp. 257-464. Springer, Heidelberg (2002)

Kydland, F.E., Prescott, E.C.: Time to build and aggregate fluctuations. Econometrica 50, 1345-1370 (1982)

Lüken, S.: The german employment accounts for national accounts and labour market statistics. Experiences and findings of six decades. Wirtsch Stat 5, 385-405 (2012)

Mai, C.: Der Arbeitsmarkt im Zeichen der Finanz- und Wirtschaftskrise. Wirtsch Stat 2, 237-247 (2010)

Meyer, M., Modde, J., Glushanok, I.: Krankheitsbedingte Fehlzeiten in der deutschen Wirtschaft im Jahr 2013. In: Badura, B., Ducki, A., Schröder, H., Klose, J., Meyer, M. (eds.) Fehlzeiten-Report 2014, pp. 323-511. Springer, Heidelberg (2014)

Möller, J.: The German labor market response in the world recession demystifying a miracle. Z Arbeitsmarkt Berufsforsch 4, 325-336 (2009)

Möller, J.: In the aftermath of the German labour market reforms, is there a qualitative/quantitative trade-off? Eur J Econ Econ Policies 11, 205-220 (2014)

Ohanian, L.E., Raffo, A.: Aggregate hours worked in OECD countries: new measurement and implications for business cycles. J Monet Econ 59, 40-56 (2012)

Pfeffermann, D., Tiller, R.: Small-area estimation with state-space models subject to benchmark constraints. J Am Stat Assoc 101, 1387-1397 (2006)

Räth, N., Braakmann, A.: Generalrevision der Volkswirtschaftlichen Gesamtrechnungen 2014 für den Zeitraum 1991 bis 2014. Wirtsch Stat 9, 502-543 (2014)

Reyher, L., Kohler, H.: Arbeitszeit und Arbeitsvolumen: Die empirische Basis der Arbeitszeit-Politik. Beiträge zur Arbeitsmarktund Berufsforschung, vol. 75. Institut für Arbeitsmarkt- und Berufsforschung, Nürnberg (1986)

Saborowski, C., Schupp, J., Wagner, G.: Urlaub in Deutschland: Erwerbstätige nutzen ihren Urlaubsanspruch oftmals nicht aus. DIW Wochenber 71(14), 171-176 (2004)

Schmidt, T., Voss, D.: Arbeitsmarkt- und geschlechtsdifferenzielle Einflussfaktoren für die Ausübung einer geringfügigen Nebenbeschäftigung. Ind Bezieh 21, 36-57 (2014)

Schnitzlein, D.: Umfang und Folgen der Nichtinanspruchnahme von Urlaub in Deutschland. DIW-Wochenbericht 78(51/52), 14-20 (2011)

Seifert, H.: Zeitkonten - Arbeit à la carte? Neue Modelle der Arbeitszeitgestaltung. In: Klenner, C., Seifert, H. (eds.) Modellwechsel durch Arbeitszeitkonten, pp. 9-26. VSA, Hamburg (1998)

Seifert, H.: Zeitkonten: Von der Normalarbeitszeit zu kontrollierter Flexibilität. WSI Mitt 54, 334-340 (2001)

Shimer, R.: Labor markets and business cycles. Princeton University Press, Princeton (2010)

Steward, J.: The Importance and Challenges of Measuring Work Hours. Iza World Labor 2014, 95 (2014). doi:10.15185/izawol. 95

Walwei, U.: Folgen der Finanzkrise: Wie robust ist der deutsche Arbeitsmarkt? Arbeit 19(2/3), 116-131 (2010)
Wanger, S.: Arbeitszeit und Arbeitsvolumen in der Bundesrepublik Deutschland 1970-1990. Beiträge zur Arbeitsmarkt- und Berufsforschung, vol. 274. Institut für Arbeitsmarkt- und Berufsforschung, Nürnberg (2003)

Wanger, S.: Erwerbstätigkeit, Arbeitszeit und Arbeitsvolumen nach Geschlecht und Altersgruppen - Ergebnisse der IAB-Arbeitszeitrechnung nach Geschlecht und Alter für die Jahre 1991-2004. IAB-Forschungsbericht, vol. 2. Institut für Arbeitsmarkt- und Berufsforschung, Nürnberg (2006)

Wanger, S.: Altersteilzeit - Beliebt aber nicht zukunftsgerecht. IABKurzbericht, vol. 8. Institut für Arbeitsmarkt- und Berufsforschung, Nürnberg (2009)

Wanger, S.: Ungenutzte Potenziale in der Teilzeit: Viele Frauen würden gerne länger arbeiten. IAB-Kurzbericht, vol. 9. Institut für Arbeitsmarkt- und Berufsforschung, Nürnberg (2011)

Wanger, S.: Arbeitszeit und Arbeitsvolumen in Deutschland - Methodische Grundlagen und Ergebnisse der Arbeitszeitrechnung. Wirtsch Sozialstat Arch 7, 31-69 (2013)

Wanger, S.: Frauen und Männer am Arbeitsmarkt: Traditionelle Erwerbs- und Arbeitszeitmuster sind nach wie vor verbreitet. IAB-Kurzbericht, vol. 4. Institut für Arbeitsmarkt- und Berufsforschung, Nürnberg (2015)

Wanger, S., Weigand, R., Zapf, I.: Revision der IAB-Arbeitszeitrechnung 2014. Grundlagen, methodische Weiterentwicklungen sowie ausgewählte Ergebnisse im Rahmen der Revision der Volkswirtschaftlichen Gesamtrechnungen. IAB-Forschungsbericht, vol. 9. Institut für Arbeitsmarkt- und Berufsforschung, Nürnberg (2014)

Weber, E., Wanger, S., Weigand, R., Zapf, I.: Verbreitung von Überstunden in Deutschland. Aktueller Bericht, Institut für Arbeitsmarkt- und Berufsforschung (2014). http://doku.iab.de/aktuell/ 2014/aktueller_bericht_1407.pdf. Accessed 29 April 2015

Weigand, R., Wanger, S., Zapf, I.: Factor structural time series models for official statistics with an application to hours worked in Germany. IAB-Discussion Paper, vol. 22. Institut für Arbeitsmarktund Berufsforschung, Nürnberg (2015)

Zapf, I.: Flexibilität am Arbeitsmarkt durch Überstunden und Arbeitszeitkonten. IAB-Forschungsbericht, vol. 3. Institut für Arbeitsmarkt- und Berufsforschung, Nürnberg (2012)

Susanne Wanger is a senior researcher at the Institute for Employment Research in Nuremberg. She studied social sciences at the University of Erlangen Nuremberg. She is part of the research department forecasts and structural analyses. Her current fields of research include the IAB Working Time Measurement Concept, part-time employment and working time.

Roland Weigand is a senior researcher at the Institute for Employment Research in Nuremberg. He studied economics at the University of Regensburg. In 2014 he received his Ph.D. He is part of the research department forecasts and structural analyses. His current fields of research include time series analyses, financial econometrics and macroeconometrics.

Ines Zapf is a senior researcher at the Institute for Employment Research in Nuremberg. She studied sociology at the University of Bamberg. In 2015 she received her Ph.D. She is part of the research department forecasts and structural analyses. Her current fields of research include the IAB Working Time Measurement Concept, overtime and working-time accounts. 